Keywords: TTT, high-level waste glasses, DWPF, crystallization, durability

Retention: Permanent

\title{
TIME-TEMPERATURE-TRANSFORMATION (TTT) DIAGRAMS FOR FUTURE WASTE COMPOSITIONS
}

\author{
A.L. Billings \\ T.B. Edwards
}

July 2010

Savannah River National Laboratory Savannah River Nuclear Solutions Aiken, SC 29808

Prepared for the U.S. Department of Energy under contract number DE-AC09-08SR22470.

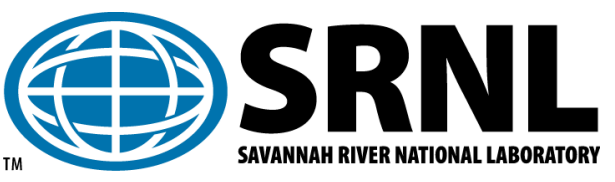


SRNL-STI-2010-00373

Revision 0

\section{DISCLAIMER}

This work was prepared under an agreement with and funded by the U.S. Government. Neither the U.S. Government or its employees, nor any of its contractors, subcontractors or their employees, makes any express or implied:

1. warranty or assumes any legal liability for the accuracy, completeness, or for the use or results of such use of any information, product, or process disclosed; or

2. representation that such use or results of such use would not infringe privately owned rights; or

3. endorsement or recommendation of any specifically identified commercial product, process, or service.

Any views and opinions of authors expressed in this work do not necessarily state or reflect those of the United States Government, or its contractors, or subcontractors.

\section{Printed in the United States of America \\ Prepared for \\ U.S. Department of Energy}




\section{REVIEWS AND APPROVALS}

AUTHORS:
A.L. Billings, Process Technology Programs
Date

T.B. Edwards, Applied Computational Engineering and Statistics

Date

TECHNICAL REVIEW:

D.K. Peeler, Process Technology Programs

Date

APPROVAL:

C.C. Herman, Manager

Date

Process Technology Programs

S.L. Marra, Manager

Date

Environmental \& Chemical Process Technology Research Programs

J.E. Occhipinti, Manager

Date

Waste Solidification Engineering 
SRNL-STI-2010-00373

Revision 0

\section{EXECUTIVE SUMMARY}

As a part of the Waste Acceptance Product Specifications (WAPS) for Vitrified High-Level Waste Forms defined by the Department of Energy - Office of Environmental Management, the waste form stability must be determined for each of the projected high-level waste (HLW) types at the Savannah River Site (SRS). Specifically, WAPS 1.4.1 requires the glass transition temperature $\left(\mathrm{T}_{\mathrm{g}}\right)$ to be defined and time-temperature-transformation (TTT) diagrams to be developed. The $\mathrm{T}_{\mathrm{g}}$ of a glass is an indicator of the approximate temperature where the supercooled liquid converts to a solid on cooling or conversely, where the solid begins to behave as a viscoelastic solid on heating. A TTT diagram identifies the crystalline phases that can form as a function of time and temperature for a given waste type or more specifically, the borosilicate glass waste form. In order to assess durability, the Product Consistency Test (PCT) was used and the durability results compared to the Environmental Assessment (EA) glass.

The measurement of glass transition temperature and the development of TTT diagrams have already been performed for the seven Defense Waste Processing Facility (DWPF) projected compositions as defined in the Waste Form Compliance Plan (WCP) and in SRNL-STI-200900025. Additional phase transformation information exists for other projected compositions, but overall these compositions did not cover composition regions estimated for future waste processing.

To develop TTT diagrams for future waste types, the Savannah River National Laboratory (SRNL) fabricated two caches of glass from reagent grade oxides to simulate glass compositions which would be likely processed with and without $\mathrm{Al}$ dissolution. These were used for glass transition temperature measurement and TTT diagram development. The glass transition temperatures of both glasses were measured using differential scanning calorimetry (DSC) and were recorded to be $448{ }^{\circ} \mathrm{C}$ and $452^{\circ} \mathrm{C}$.

Using the previous TTT diagrams as guidance, subsamples of each glass were isothermally heat treated for 1 to 768 hours at temperatures between $500^{\circ} \mathrm{C}$ to $1000{ }^{\circ} \mathrm{C}$. Each of the heat treated samples, along with quenched and centerline canister cooled (CCC) treated samples, were analyzed using X-ray diffraction (XRD) and the PCT. Maximum crystallization was detected in samples treated at $700{ }^{\circ} \mathrm{C}$ and $600{ }^{\circ} \mathrm{C}$ for more than 96 hours in both glasses. Phases crystallized were similar in composition if not the same as those found in the previous TTT studies. Six different crystalline phases were detected, including nepheline, aegirine, lithium silicate, trevorite (spinel based), krinovite, and calcium magnesium iron silicon oxide. Overall, phases were spinel (iron) based, lithium metasilicate, sodium aluminosilicate or alkali transition metal silicate in composition. No new crystalline families were detected. Durability, as measured by the PCT, decreased when lithium silicate or nepheline crystals were present. The conclusions of this study were consistent with previous studies.

In order to continue to meet the requirements of the WCP, a simplified strategy is suggested for the generation of future TTT diagrams. Only extremely significant changes in composition resulting from processing strategy changes would require generating more TTT diagrams. 


\section{TABLE OF CONTENTS}

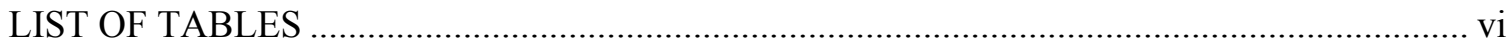

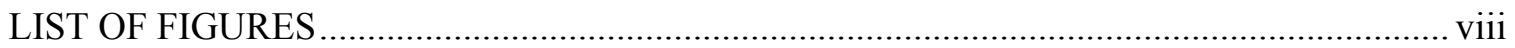

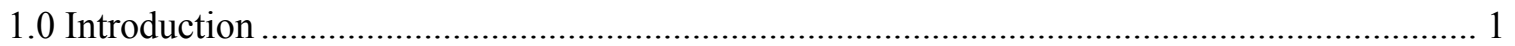

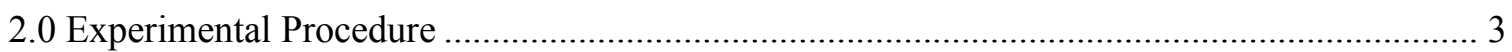

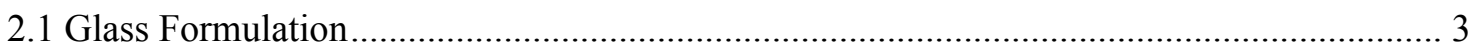

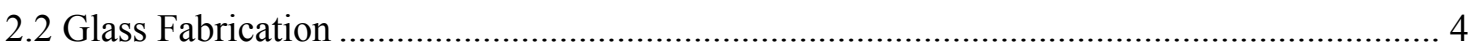

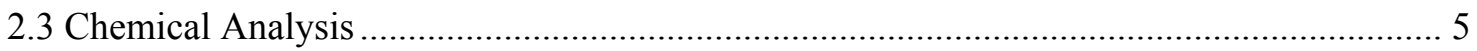

2.4 Glass Transition Temperature Determination.................................................................... 5

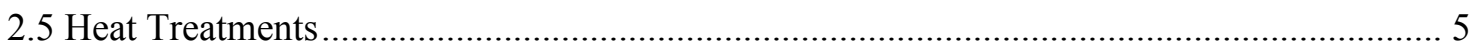

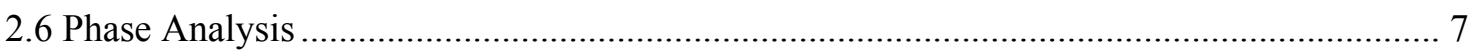

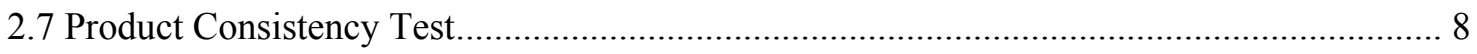

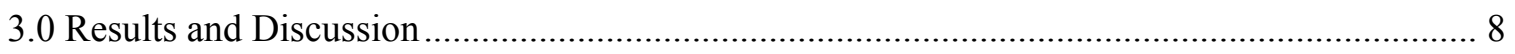

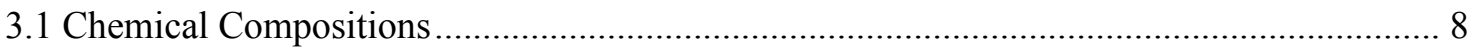

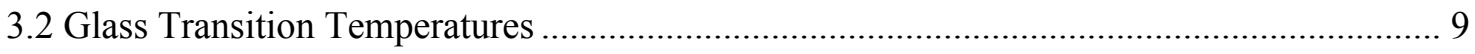

3.3 Phase Analysis (XRD Qualitative and Quantitative) .................................................... 10

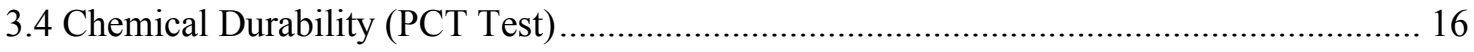

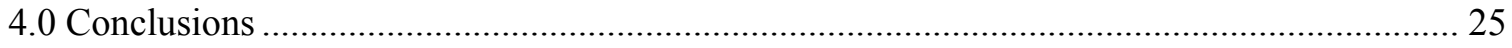

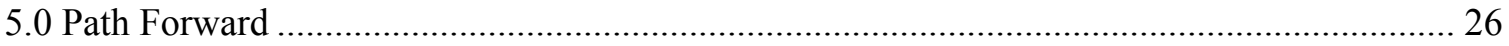

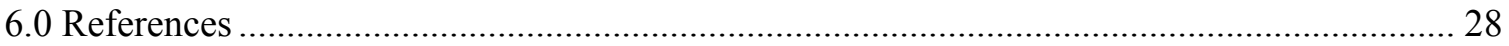

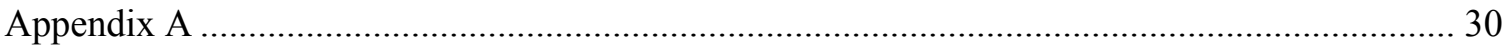




\section{LIST OF TABLES}

Table 1-1. Representative, Renormalized (without $\mathrm{ThO}_{2}$ and $\mathrm{U}_{3} \mathrm{O}_{8}$ ) Cluster 2 and Cluster 4 Glass Compositions ${ }^{6}$ 3

Table 2-1. Targeted Glass Compositions for TTT Study ........................................................... 4

Table 2-2. Sample Identification, Treatment Times and Temperatures for C2-510 Glasses ......... 6

Table 2-3. Sample Identification, Treatment Times and Temperatures for C4-418 Glasses ......... 7

Table 3-1. Target and Overall Measured Concentrations by Weight Percent Oxide for the Cache

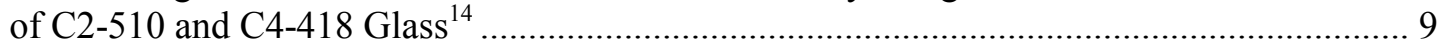

Table 3-2. Crystalline Phases of the Heat Treated Sample Detected With X-ray Diffraction for C2-510 Glass. 11

Table 3-3 Crystalline Phases of the Heat Treated Sample Detected With X-ray Diffraction for C4418 Glass

Table 3-4. Quantitative XRD Results for Selected Glasses .................................................... 15

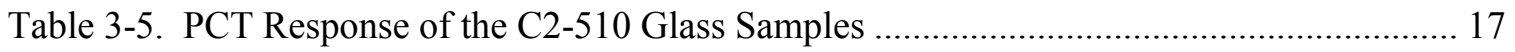

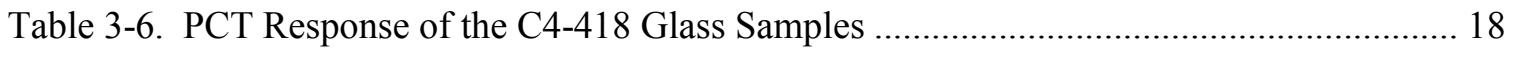

Table 3-7. PCT Response of the EA and ARM Glass References ............................................ 18

Table 3-8. Quantitative XRD Results and Normalized B Release for Select Samples of the C2510 Glass

Table 3-9. Quantitative XRD Results and Normalized B Release for Select Samples of the C4418 Glass

Table A-1. Waste Form Compositions of Various Glasses Used to Generate TTT Diagrams ${ }^{2,22-24}$

Table A-2. Measured Elemental Release of the PCT Leachates of ARM, EA and Blank Samples

Table A-3. Measured Elemental Results of the ICP Standards

Table A-4. Measured Elemental Release of the PCT Leachates for C2 - Frit 510 Glass Samples

Table A-5. Measured Elemental Release of the PCT Leachates for C2 - Frit 510 Glass Samples

Table A-6. Measured Elemental Release of the PCT Leachates for C2 - Frit 510 and C4 - 418 Glass Samples ......

Table A-7. Measured Elemental Release of the PCT Leachates for the C4 - 418 Glass Samples 
SRNL-STI-2010-00373

Revision 0

Table A-8. Measured Elemental Release of the PCT Leachates for the C4 - 418 Glass Samples 38

Table A-9. Measured Elemental Release of the PCT Leachates for the C4 - 418 Glass Samples

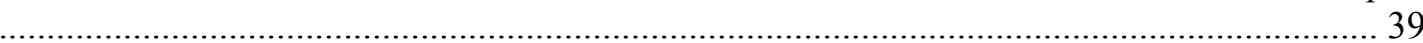


SRNL-STI-2010-00373

Revision 0

\section{LIST OF FIGURES}

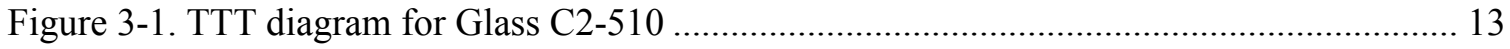

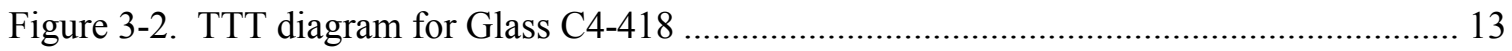

Figure 3-3. Normalized Li Release as a Function of Temperature and Duration of Heat Treatment

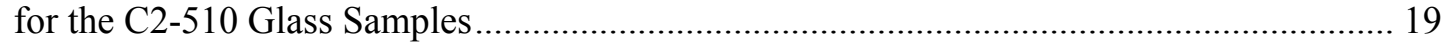

Figure 3-4. Normalized B Release as a Function of Temperature and Duration of Heat Treatment for the C2-510 Glass Samples

Figure 3-5. Normalized $\mathrm{Na}$ Release as a Function of Temperature and Duration of Heat

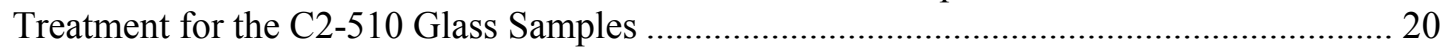

Figure 3-6. Normalized Si Release as a Function of Temperature and Duration of Heat Treatment

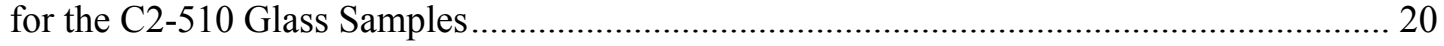

Figure 3-7. Normalized Li Release as a Function of Temperature and Duration of Heat Treatment

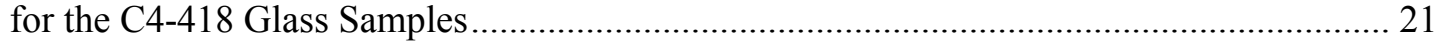

Figure 3-8. Normalized B Release as a Function of Temperature and Duration of Heat Treatment

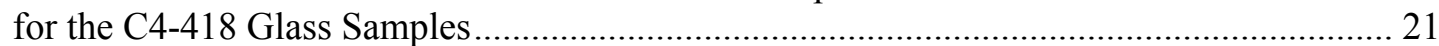

Figure 3-9. Normalized $\mathrm{Na}$ Release as a Function of Temperature and Duration of Heat Treatment for the C4-418 Glass Samples

Figure 3-10. Normalized Si Release as a Function of Temperature and Duration of Heat Treatment for the C4-418 Glass Samples 
SRNL-STI-2010-00373

Revision 0

\section{LIST OF ABBREVIATIONS}

\begin{tabular}{ll} 
ARM & Approved Reference Material \\
BCH & Batch 1 Reference Glass \\
CCC & Centerline canister cooling \\
DOE & Department of Energy \\
DSC & Differential Scanning Calorimetry \\
DWPF & Defense Waste Processing Facility \\
EA & Environmental Assessment \\
HLW & High-Level Waste \\
ICP-AES & Inductively Coupled Plasma - Atomic Emission Spectroscopy \\
LM & Lithium Metaborate \\
MAR & Measurement Acceptability Region \\
PCT & Product Consistency Test \\
PF & Peroxide Fusion \\
PSAL & Process Science Analytical Laboratory \\
SB & Sludge Batch \\
SRNL & Savannah River National Laboratory \\
SRS & Savannah River Site \\
$T_{g}$ & Glass Transition Temperature \\
$T_{L}$ & Liquidus Temperature \\
TTQAP & Task Technical \& Quality Assurance Plan \\
TTR & Technical Task Request \\
TTT & Time-Temperature-Transformation \\
WAPS & Waste Acceptance Product Specifications \\
WCP & Waste Form Compliance Plan \\
WL & Waste Loading \\
WQR & Waste Form Qualification Report \\
XRD & X-ray Diffraction \\
& \\
\hline
\end{tabular}




\subsection{Introduction}

Glasses, which are amorphous by definition, can transform into more ordered crystalline phases at temperatures below the liquidus $\left(\mathrm{T}_{\mathrm{L}}\right)$ and above the glass transition temperature $\left(\mathrm{T}_{\mathrm{g}}\right)$. By annealing a glass within this glass transformation region, the potential for crystal nucleation and growth is high. In nuclear waste glasses, this transformation region is relatively large, encompassing approximately $400{ }^{\circ} \mathrm{C}$ to $1050{ }^{\circ} \mathrm{C}$. The crystallization kinetics of nuclear waste glasses can be determined by creating time-temperature-transformation (TTT) diagrams. This provides information regarding the processing conditions necessary to avoid significant devitrification, which can alter the long-term durability of the waste glass. Generating these curves is also important for nuclear waste glasses as they provide the effects of different accident scenarios (low temperature melter idling, transportation fires).

The Defense Waste Processing Facility (DWPF) is currently immobilizing high-level liquid waste (HLW) by combining sludge and streams from salt processing with frit (a prefabricated glass), melting the slurry mix of waste streams and frit and pouring the molten glass into stainless steel canisters to create the final waste form at the Savannah River Site (SRS). Eventually, these canistered waste forms will be sent to the Civilian Radioactive Waste Management System (repository) for final disposal. In order to assure acceptance by the repository, the Department of Energy (DOE) has defined requirements which DWPF canistered waste forms must meet. These requirements are the Waste Acceptance Product Specifications (WAPS). ${ }^{1}$ WAPS 1.4.1 requires the measurement of $\mathrm{T}_{\mathrm{g}}$ and the development of TTT diagrams for the projected waste types to be processed through the facility. The TTT diagrams identify the duration of exposure at any temperature that causes significant changes in either the phase structure or the phase compositions. Additionally, the effects of changes of phase composition on the results of the Product Consistency Test (PCT) are determined. Prior to radioactive operations, glass transition temperatures and TTT diagrams were completed for seven projected compositions (known as the Waste Form Compliance Plan (WCP) glasses) originally anticipated to bound the range of waste types anticipated for the DWPF. ${ }^{2}$ TTT diagrams were developed for the WCP glass compositions in addition to previously developed diagrams for specific frit and waste compositions. Since that time, higher waste loadings, less sludge washing, and different tank blending scenarios and salt processing strategies have been implemented. In addition, frit development strategies have significantly changed, resulting in higher alkali glass systems being processed to improve melt rate, waste loading, and waste throughput. As a result of these changes, a TTT diagram and the glass transition temperature were measured for one specific waste type previously processed at DWPF. A TTT diagram for Sludge Batch 3 (SB3), Frit 418 at a $38 \mathrm{wt} \%$ waste loading (WL) was created and the waste form was characterized for the required properties in the report by Billings and Edwards. ${ }^{3}$ Results of that particular study suggested even with significant changes in the glass composition, the type of crystalline phases precipitated were part of the same compositional families as the seven WCP glasses. Properties of those heat treated glasses, such as the $\mathrm{T}_{\mathrm{g}}$ and PCT release, were also similar with respect to the WCP glasses.

Future waste types and glass compositions are anticipated to be different than the previously evaluated SB3 - Frit 418 composition and WCP compositions. To identify the potential phase compositions for these future processing regions, a strategy has been developed that would require completing more TTT diagrams for two averaged, future, predicted waste types. This task was requested by DWPF under the Technical Task Request HLW-DWPF-TTR-2009-0006 and outlined by SRNL in the Task Technical \& Quality Assurance Plan (TTQAP) SRNL-RP2009-00284. ${ }^{4,5}$ Since the results of the Frit 418-SB3 study showed little change in the types of crystalline phases formed after heat treatment as compared to the TTT diagrams for the WCP 
glasses, it is unlikely that extreme differences will occur in the TTT diagram for future waste forms as long as the properties remain within the DWPF operating bounds. By creating TTT diagrams for the resulting glass compositions of future averaged waste types, insight will be provided to the crystallization regions possible for those averages. It will also supply experimental data to establish any possible difference in the phases formed or different temperatures at which crystallization will occur. If the results are not significantly different from the WCP glasses, the SB3-Frit 418 composition, or other analyzed glass compositions, it would negate the need to create TTT diagrams for each sludge batch or glass composition produced at the DWPF.

As discussed in the report, "Initial MAR Assessments to Access the Impact of Al-Dissolution on DWPF Operating Windows", 6 the majority of future waste compositions (as defined by Revision 13 of the High Level Waste System's Plan) could be grouped into two flowsheet scenarios, with and without Al-dissolution. Compositions Cluster 2 (without Al-dissolution) and Cluster 4 (with Al-dissolution) represent these average waste projections. Measurement Acceptability Region (MAR) assessments were completed on the two clusters that identified candidate frits that could be used to process these future waste types over waste loadings of interest. Based on that study, two specific glass forming systems were identified to support the development of TTT diagrams for future sludge batches. The specific glass forming systems selected were:

Cluster 2 combined with Frit 510 at a 34 wt \% WL

Cluster 4 combined with Frit 418 at a 38 wt \% WL

The compositions of these waste forms as evaluated in the report by Newell et al. are found in Table 1-1. 
SRNL-STI-2010-00373

Revision 0

Table 1-1. Representative, Renormalized (without $\mathrm{ThO}_{2}$ and $\mathrm{U}_{3} \mathrm{O}_{8}$ ) Cluster 2 and Cluster 4 Glass Compositions ${ }^{6}$

\begin{tabular}{|c|c|c|}
\hline $\begin{array}{c}\text { Oxide } \\
(\text { wt \%) }\end{array}$ & $\begin{array}{c}\text { Cluster 2- } \\
\text { Frit } 510\end{array}$ & $\begin{array}{c}\text { Cluster 4- } \\
\text { Frit } 418\end{array}$ \\
\hline $\mathrm{Al}_{2} \mathrm{O}_{3}$ & 8.577 & 6.034 \\
\hline $\mathrm{B}_{2} \mathrm{O}_{3}$ & 9.240 & 4.960 \\
\hline $\mathrm{BaO}$ & 0.078 & 0.104 \\
\hline $\mathrm{CaO}$ & 0.976 & 1.345 \\
\hline $\mathrm{Ce}_{2} \mathrm{O}_{3}$ & 0.206 & 0.241 \\
\hline $\mathrm{Cr}_{2} \mathrm{O}_{3}$ & 0.099 & 0.141 \\
\hline $\mathrm{CuO}$ & 0.030 & 0.043 \\
\hline $\mathrm{Fe}_{2} \mathrm{O}_{3}$ & 11.441 & 14.521 \\
\hline $\mathrm{K}_{2} \mathrm{O}$ & 0.068 & 0.094 \\
\hline $\mathrm{La}_{2} \mathrm{O}_{3}$ & 0.074 & 0.090 \\
\hline $\mathrm{Li}_{2} \mathrm{O}$ & 5.280 & 4.960 \\
\hline $\mathrm{MgO}$ & 0.153 & 0.192 \\
\hline $\mathrm{MnO}$ & 1.484 & 2.135 \\
\hline $\mathrm{Na}_{2} \mathrm{O}$ & 12.801 & 13.717 \\
\hline $\mathrm{NiO}$ & 0.430 & 0.527 \\
\hline $\mathrm{PbO}$ & 0.089 & 0.105 \\
\hline $\mathrm{SiO}_{2}$ & 47.444 & 49.222 \\
\hline $\mathrm{SO}_{4}{ }^{2-}$ & 0.074 & 0.104 \\
\hline $\mathrm{TiO}_{2}$ & 1.223 & 1.144 \\
\hline $\mathrm{ZnO}$ & 0.046 & 0.067 \\
\hline $\mathrm{ZrO}_{2}$ & 0.188 & 0.254 \\
\hline Sum & 100.000 & 100.000 \\
\hline
\end{tabular}

\subsection{Experimental Procedure}

\subsection{Glass Formulation}

Two single stocks of simulated Cluster 2 - Frit 510 (C2-510) glass and Cluster 4 - Frit 418 (C4418) glass were used to support the chemical and physical characterization associated with developing new TTT diagrams for the future compositional regions. The current study was based on non-radioactive glasses in order to be consistent with the earlier TTT studies. ${ }^{2,3}$ More specifically, the sludge composition was renormalized without $\mathrm{U}_{3} \mathrm{O}_{8}$ and $\mathrm{ThO}_{2}$. As mentioned earlier, glass compositions were taken from the report, "Initial MAR Assessments to Access the Impact of Al-Dissolution on DWPF Operating Windows". ${ }^{\mathrm{RuO}_{2}}$ was also added to the glass compositions at $0.10 \mathrm{wt} \%$ because it is present as a minor component in the sludge and represents an average of what is projected to be present in future waste compositions. It was included in this testing because noble metals such as $\mathrm{RuO}_{2}$ are not fully soluble in the glass and will often serve as nucleation sites for crystallization. ${ }^{7}$ The final targeted compositions are listed in Table 2-1. 
SRNL-STI-2010-00373

Revision 0

Table 2-1. Targeted Glass Compositions for TTT Study

\begin{tabular}{|c|c|c|}
\hline Name & $\begin{array}{c}\text { Cluster 2- } \\
\text { Frit } 510\end{array}$ & $\begin{array}{c}\text { Cluster 4- } \\
\text { Frit } 418\end{array}$ \\
\hline $\begin{array}{l}\text { Waste } \\
\text { Loading }\end{array}$ & 34 wt $\%$ & $38 \mathrm{wt} \%$ \\
\hline \multicolumn{3}{|c|}{ Oxide (wt \%) } \\
\hline $\mathrm{Al}_{2} \mathrm{O}_{3}$ & 8.55 & 6.02 \\
\hline $\mathrm{B}_{2} \mathrm{O}_{3}$ & 9.24 & 4.96 \\
\hline $\mathrm{BaO}$ & 0.08 & 0.10 \\
\hline $\mathrm{CaO}$ & 0.97 & 1.34 \\
\hline $\mathrm{Ce}_{2} \mathrm{O}_{3}$ & 0.21 & 0.24 \\
\hline $\mathrm{Cr}_{2} \mathrm{O}_{3}$ & 0.10 & 0.14 \\
\hline $\mathrm{CuO}$ & 0.03 & 0.04 \\
\hline $\mathrm{Fe}_{2} \mathrm{O}_{3}$ & 11.41 & 14.48 \\
\hline $\mathrm{K}_{2} \mathrm{O}$ & 0.07 & 0.09 \\
\hline $\mathrm{La}_{2} \mathrm{O}_{3}$ & 0.07 & 0.09 \\
\hline $\mathrm{Li}_{2} \mathrm{O}$ & 5.28 & 4.96 \\
\hline $\mathrm{MgO}$ & 0.15 & 0.19 \\
\hline $\mathrm{MnO}$ & 1.48 & 2.13 \\
\hline $\mathrm{Na}_{2} \mathrm{O}$ & 12.78 & 13.69 \\
\hline $\mathrm{NiO}$ & 0.43 & 0.53 \\
\hline $\mathrm{PbO}$ & 0.09 & 0.11 \\
\hline $\mathrm{RuO}_{2}$ & 0.10 & 0.10 \\
\hline $\mathrm{SiO}_{2}$ & 47.44 & 49.22 \\
\hline $\mathrm{SO}_{4}{ }^{2-}$ & 0.07 & 0.10 \\
\hline $\mathrm{TiO}_{2}$ & 1.22 & 1.14 \\
\hline $\mathrm{ZnO}$ & 0.05 & 0.07 \\
\hline $\mathrm{ZrO}_{2}$ & 0.19 & 0.25 \\
\hline Sum & 100.00 & 100.00 \\
\hline
\end{tabular}

\subsection{Glass Fabrication}

It should be noted that kilogram quantities of each of the glasses were required to support this task. This required multiple individual batches targeting the same composition to be melted and then combined into one large cache of glass. Glass was batched and melted following the standard SRNL procedures. ${ }^{8,9}$ The glasses were prepared from the proper proportions of reagentgrade oxides, carbonates, boric acid, and salts in twelve $300 \mathrm{~g}$ batches (numbered 1-12). The batch sheets and other experimental notes can be found in the laboratory notebooks WSRC-NB2006-00074 and SRNL-NB-2009-00121. ${ }^{10,11}$ The raw materials were thoroughly mixed and placed into $95 \%$ platinum $/ 5 \%$ gold, $600 \mathrm{~mL}$ crucibles. The crucibles were placed into an electrically heated, high-temperature furnace at the target melt temperature of $1150{ }^{\circ} \mathrm{C}$. After an isothermal hold at $1150{ }^{\circ} \mathrm{C}$ for 1.0 hour, the crucibles were removed from the furnace and poured onto a clean, stainless steel plate and allowed to air cool (quench). The glasses were then crushed and pairs of the twelve $300 \mathrm{~g}$ batches were combined into six $600 \mathrm{~g}$ batches (named C2-510 A-F and $\mathrm{C} 4-418 \mathrm{~A}-\mathrm{F}$ ) and re-melted at $1150{ }^{\circ} \mathrm{C}$ for $1.0 \mathrm{~h}$ of homogenization following the same procedure as above. 


\subsection{Chemical Analysis}

To confirm that the as-fabricated glasses corresponded to the defined target composition, representative samples of each of the $600 \mathrm{~g}$ glass batches were submitted to the SRNL Process Science Analytical Laboratory (PSAL) for chemical analysis under the auspices of the analytical plan SRNL-L5200-2009-00019. ${ }^{12}$ The cations were analyzed by means of two dissolution techniques, sodium peroxide fusion (PF) and lithium-metaborate fusion (LM). The samples prepared by LM were used to measure aluminum $(\mathrm{Al})$, barium $(\mathrm{Ba})$, calcium $(\mathrm{Ca})$, cerium $(\mathrm{Ce})$, chromium $(\mathrm{Cr})$, copper $(\mathrm{Cu})$, iron $(\mathrm{Fe})$, potassium $(\mathrm{K})$, lanthanum $(\mathrm{La})$, magnesium $(\mathrm{Mg})$, manganese $(\mathrm{Mn})$, sodium, $(\mathrm{Na})$, nickel $(\mathrm{Ni})$, lead $(\mathrm{Pb})$, ruthenium $(\mathrm{Ru})$, sulfur $(\mathrm{S})$, silicon $(\mathrm{Si})$, titanium $(\mathrm{Ti})$, zinc $(\mathrm{Zn})$, and zirconium $(\mathrm{Zr})$ concentrations. Samples prepared by PF were used to measure boron (B) and lithium (Li) concentrations. Each glass was prepared in duplicate for each cation dissolution technique. All of the prepared samples were analyzed by Inductively Coupled Plasma - Atomic Emission Spectroscopy (ICP-AES) with the instrumentation being recalibrated between the duplicate analyses. Glass standards were also intermittently measured to assess the performance of the ICP-AES instrument over the course of the analyses. Specifically, several samples of WCP Batch $1(\mathrm{BCH})^{13}$ were included in the sample analysis.

Results of the chemical analyses were reviewed before initiation of any measurements or heat treatments. ${ }^{14}$ The objective of the review was to facilitate a decision on the use of all or only a subset of the available batches of glass (A-F) for each glass composition. The individual batches determined to be compositionally consistent could then be combined in order to create a cache of compositionally consistent glass that could be used to support the glass transition measurement and TTT study. The result of the statistical review of the measured compositions found no major issues with the measured compositions of the six batches associated with each of the two targeted compositions. There were some minor issues, however, with the $\mathrm{CaO}$ measurements for one of the $\mathrm{C} 2-510$ system batches, namely C2-510-F; and as a result, this batch, C2-510-F, was excluded from the cache of glass for the C2-510 TTT diagram generation. Eliminating batch F from the cache ensured that a compositionally consistent glass would be used to support programmatic objectives. In addition, based upon the results of this review, it was recommended that all six of the C4-418 batches were to be used to prepare the cache of glass for the C4-418 system. ${ }^{14}$ Batches C4-418 A-F were then combined and mixed thoroughly in one container where samples could subsequently be drawn for heat treatments and the same was done for C2-510 A-E.

\subsection{Glass Transition Temperature Determination}

A Netzsch 409 PC Luxx differential scanning calorimeter (DSC) was used to measure the glass transition temperature $\left(\mathrm{T}_{\mathrm{g}}\right)$ of each of the glasses. The ASTM procedure E 1356 was also used as a guide for determining the $\mathrm{T}_{\mathrm{g}}{ }^{15}$ Small chips of glass from each cache of TTT glass were used for analysis. A heating rate of $20 \mathrm{~K} / \mathrm{min}$ was used to heat three separate samples from room temperature to $1000{ }^{\circ} \mathrm{C}$ in a platinum pan. The value of $\mathrm{T}_{\mathrm{g}}$ reported in this document was determined by the slope intercept method at the onset of the endothermic inflection and is the average of three separate tests.

\subsection{Heat Treatments}

In order to develop TTT diagrams for each glass composition, glasses were heat treated as follows. Approximately $30 \mathrm{~g}$ of glass from the chemically verified cache were placed in open platinum alloy crucibles and re-melted at $1150{ }^{\circ} \mathrm{C}$ for 1 hour. Durations were kept at one hour holds at melting temperature in order to minimize any volatilization of the chemically verified glass, yet still maintain a homogenized melt. After an hour, the crucibles were removed from the 
furnace and placed into separate furnaces preheated to the desired isothermal hold temperature. Once the desired duration of heat treatment was reached, crucibles were removed from the furnace and immersed in a shallow water bath to quickly cool or "quench" the glass. This process only exposed the exterior of the crucible to the water (i.e., water did not contact the glass). Each glass sample was heat treated at a unique time and temperature in order to cover the anticipated crystallization region. Sample names, temperatures and durations of heat treatments are listed in Table 2-2 and Table 2-3. An independent thermocouple and temperature recorder were used during heat treatments to ensure that the temperature remained relatively constant during the treatments. A sample of each glass was also heat treated according to the centerline canister cooling (CCC) temperature profile in order to simulate DWPF pouring conditions. ${ }^{16}$ The CCC glass, along with samples of the original "quenched" glasses (non-heat treated glass from the glass cache), were submitted along with all other heat treated samples for further analysis.

Table 2-2. Sample Identification, Treatment Times and Temperatures for C2-510 Glasses

\begin{tabular}{||c|c|c|c||c|c|c|c||}
\hline \hline Sample Name & $\begin{array}{c}\text { Glass } \\
\text { Type }\end{array}$ & $\begin{array}{c}\text { Temp. } \\
\left({ }^{\circ} \mathbf{C}\right)\end{array}$ & $\begin{array}{c}\text { Time } \\
\text { (hours) }\end{array}$ & Sample Name & $\begin{array}{c}\text { Glass } \\
\text { Type }\end{array}$ & $\begin{array}{c}\text { Temp. } \\
\left({ }^{\circ} \mathbf{C}\right)\end{array}$ & $\begin{array}{c}\text { Time } \\
\text { (hours) }\end{array}$ \\
\hline \hline C2-1000-1 & $\mathrm{C} 2-510$ & 1000 & 1 & $\mathrm{C} 2-800-192$ & $\mathrm{C} 2-510$ & 800 & 192 \\
\hline $\mathrm{C} 2-1000-3$ & $\mathrm{C} 2-510$ & 1000 & 3 & $\mathrm{C} 2-800-384$ & $\mathrm{C} 2-510$ & 800 & 384 \\
\hline $\mathrm{C} 2-1000-6$ & $\mathrm{C} 2-510$ & 1000 & 6 & $\mathrm{C} 2-800-768$ & $\mathrm{C} 2-510$ & 800 & 768 \\
\hline $\mathrm{C} 2-1000-12$ & $\mathrm{C} 2-510$ & 1000 & 12 & $\mathrm{C} 2-700-6$ & $\mathrm{C} 2-510$ & 700 & 6 \\
\hline $\mathrm{C} 2-1000-24$ & $\mathrm{C} 2-510$ & 1000 & 24 & $\mathrm{C} 2-700-12$ & $\mathrm{C} 2-510$ & 700 & 12 \\
\hline $\mathrm{C} 2-1000-48$ & $\mathrm{C} 2-510$ & 1000 & 48 & $\mathrm{C} 2-700-24$ & $\mathrm{C} 2-510$ & 700 & 24 \\
\hline $\mathrm{C} 2-1000-96$ & $\mathrm{C} 2-510$ & 1000 & 96 & $\mathrm{C} 2-700-48$ & $\mathrm{C} 2-510$ & 700 & 48 \\
\hline $\mathrm{C} 2-1000-192$ & $\mathrm{C} 2-510$ & 1000 & 192 & $\mathrm{C} 2-700-96$ & $\mathrm{C} 2-510$ & 700 & 96 \\
\hline $\mathrm{C} 2-1000-384$ & $\mathrm{C} 2-510$ & 1000 & 384 & $\mathrm{C} 2-700-192$ & $\mathrm{C} 2-510$ & 700 & 192 \\
\hline $\mathrm{C} 2-1000-768$ & $\mathrm{C} 2-510$ & 1000 & 768 & $\mathrm{C} 2-700-384$ & $\mathrm{C} 2-510$ & 700 & 384 \\
\hline $\mathrm{C} 2-900-1$ & $\mathrm{C} 2-510$ & 900 & 1 & $\mathrm{C} 2-700-768$ & $\mathrm{C} 2-510$ & 700 & 768 \\
\hline $\mathrm{C} 2-900-3$ & $\mathrm{C} 2-510$ & 900 & 3 & $\mathrm{C} 2-600-12$ & $\mathrm{C} 2-510$ & 600 & 12 \\
\hline $\mathrm{C} 2-900-6$ & $\mathrm{C} 2-510$ & 900 & 6 & $\mathrm{C} 2-600-24$ & $\mathrm{C} 2-510$ & 600 & 24 \\
\hline $\mathrm{C} 2-900-12$ & $\mathrm{C} 2-510$ & 900 & 12 & $\mathrm{C} 2-600-48$ & $\mathrm{C} 2-510$ & 600 & 48 \\
\hline $\mathrm{C} 2-900-24$ & $\mathrm{C} 2-510$ & 900 & 24 & $\mathrm{C} 2-600-96$ & $\mathrm{C} 2-510$ & 600 & 96 \\
\hline $\mathrm{C} 2-900-48$ & $\mathrm{C} 2-510$ & 900 & 48 & $\mathrm{C} 2-600-192$ & $\mathrm{C} 2-510$ & 600 & 192 \\
\hline $\mathrm{C} 2-900-96$ & $\mathrm{C} 2-510$ & 900 & 96 & $\mathrm{C} 2-600-384$ & $\mathrm{C} 2-510$ & 600 & 384 \\
\hline $\mathrm{C} 2-900-192$ & $\mathrm{C} 2-510$ & 900 & 192 & $\mathrm{C} 2-600-768$ & $\mathrm{C} 2-510$ & 600 & 768 \\
\hline $\mathrm{C} 2-900-384$ & $\mathrm{C} 2-510$ & 900 & 384 & $\mathrm{C} 2-500-24$ & $\mathrm{C} 2-510$ & 500 & 24 \\
\hline $\mathrm{C} 2-900-768$ & $\mathrm{C} 2-510$ & 900 & 768 & $\mathrm{C} 2-500-48$ & $\mathrm{C} 2-510$ & 500 & 48 \\
\hline $\mathrm{C} 2-800-3$ & $\mathrm{C} 2-510$ & 800 & 3 & $\mathrm{C} 2-500-96$ & $\mathrm{C} 2-510$ & 500 & 96 \\
\hline $\mathrm{C} 2-800-6$ & $\mathrm{C} 2-510$ & 800 & 6 & $\mathrm{C} 2-500-192$ & $\mathrm{C} 2-510$ & 500 & 192 \\
\hline $\mathrm{C} 2-800-12$ & $\mathrm{C} 2-510$ & 800 & 12 & $\mathrm{C} 2-500-384$ & $\mathrm{C} 2-510$ & 500 & 384 \\
\hline $\mathrm{C} 2-800-24$ & $\mathrm{C} 2-510$ & 800 & 24 & $\mathrm{C} 2-500-768$ & $\mathrm{C} 2-510$ & 500 & 768 \\
\hline $\mathrm{C} 2-800-48$ & $\mathrm{C} 2-510$ & 800 & 48 & $\mathrm{C} 2-q u e n c h e d$ & $\mathrm{C} 2-510$ & quenched & \\
\hline $\mathrm{C} 2-800-96$ & $\mathrm{C} 2-510$ & 800 & 96 & $\mathrm{C} 2-\mathrm{CCC}$ & $\mathrm{C} 2-510$ & $\mathrm{CCC}$ & \\
\hline \hline
\end{tabular}


Table 2-3. Sample Identification, Treatment Times and Temperatures for C4-418 Glasses

\begin{tabular}{|c|c|c|c|c|c|c|c|}
\hline Sample Name & $\begin{array}{l}\text { Glass } \\
\text { Type } \\
\end{array}$ & $\begin{array}{c}\text { Temp. } \\
\left({ }^{\circ} \mathrm{C}\right)\end{array}$ & $\begin{array}{c}\text { Time } \\
\text { (hours) }\end{array}$ & Sample Name & $\begin{array}{l}\text { Glass } \\
\text { Type }\end{array}$ & $\begin{array}{c}\text { Temp. } \\
\left({ }^{\circ} \mathrm{C}\right)\end{array}$ & $\begin{array}{c}\text { Time } \\
\text { (hours) }\end{array}$ \\
\hline C4-1000-1 & C4-418 & 1000 & 1 & C4-800-192 & C4-418 & 800 & 192 \\
\hline C4-1000-3 & C4-418 & 1000 & 3 & C4-800-384 & C4-418 & 800 & 384 \\
\hline C4-1000-6 & C4-418 & 1000 & 6 & C4-800-768 & C4-418 & 800 & 768 \\
\hline C4-1000-12 & C4-418 & 1000 & 12 & C4-700-6 & C4-418 & 700 & 6 \\
\hline C4-1000-24 & C4-418 & 1000 & 24 & C4-700-12 & C4-418 & 700 & 12 \\
\hline C4-1000-48 & C4-418 & 1000 & 48 & C4-700-24 & C4-418 & 700 & 24 \\
\hline C4-1000-96 & C4-418 & 1000 & 96 & C4-700-48 & C4-418 & 700 & 48 \\
\hline C4-1000-192 & C4-418 & 1000 & 192 & C4-700-96 & C4-418 & 700 & 96 \\
\hline C4-1000-384 & C4-418 & 1000 & 384 & C4-700-192 & C4-418 & 700 & 192 \\
\hline C4-1000-840 & C4-418 & 1000 & 840 & C4-700-384 & C4-418 & 700 & 384 \\
\hline C4-900-1 & C4-418 & 900 & 1 & C4-700-768 & C4-418 & 700 & 768 \\
\hline C4-900-3 & C4-418 & 900 & 3 & C4-600-12 & C4-418 & 600 & 12 \\
\hline C4-900-6 & C4-418 & 900 & 6 & C4-600-24 & C4-418 & 600 & 24 \\
\hline C4-900-12 & C4-418 & 900 & 12 & C4-600-48 & C4-418 & 600 & 48 \\
\hline C4-900-24 & C4-418 & 900 & 24 & C4-600-96 & C4-418 & 600 & 96 \\
\hline C4-900-48 & C4-418 & 900 & 48 & C4-600-192 & C4-418 & 600 & 192 \\
\hline C4-900-96 & C4-418 & 900 & 96 & C4-600-384 & C4-418 & 600 & 384 \\
\hline C4-900-192 & C4-418 & 900 & 192 & C4-600-768 & C4-418 & 600 & 768 \\
\hline C4-900-384 & C4-418 & 900 & 384 & C4-500-24 & C4-418 & 500 & 24 \\
\hline C4-900-840 & C4-418 & 900 & 840 & C4-500-48 & C4-418 & 500 & 48 \\
\hline C4-800-3 & C4-418 & 800 & 3 & C4-500-96 & C4-418 & 500 & 96 \\
\hline C4-800-6 & C4-418 & 800 & 6 & C4-500-192 & C4-418 & 500 & 192 \\
\hline C4-800-12 & C4-418 & 800 & 12 & C4-500-384 & C4-418 & 500 & 384 \\
\hline C4-800-24 & C4-418 & 800 & 24 & $\mathrm{C} 4-500-840^{\mathrm{a}}$ & C4-418 & 500 & 840 \\
\hline C4-800-48 & C4-418 & 800 & 48 & C4-quenched & C4-418 & quenched & \\
\hline C4-800-96 & C4-418 & 800 & 96 & C4-CCC & C4-418 & $\mathrm{CCC}$ & \\
\hline
\end{tabular}

a These samples were left in furnace longer than targeted treatment time. The samples were exposed to temperature 840 hours instead of the planned 768 hours.

\subsection{Phase Analysis}

Glass samples were evaluated for crystallization using X-ray Diffraction (XRD). Depending on the type and extent of crystallization, the existence of crystalline phases in the glass can impact properties such as durability. The crystallization information may also provide insight into the potential liquidus temperature $\left(\mathrm{T}_{\mathrm{L}}\right)$ of the glass since crystals should not be identified above the $\mathrm{T}_{\mathrm{L}}$. Samples were run under conditions providing a detection limit of approximately $0.5 \mathrm{vol} \%$. That is, if crystals (or undissolved solids) were present at $0.5 \mathrm{vol} \%$ or greater, the diffractometer would not only be capable of detecting the crystals but would also allow a qualitative determination of the type of crystal(s) present. Jade $9.0^{\circ}$ software was used for phase analysis.

For those samples which exhibited a crystalline phase other than Trevorite (or other spinel based phase) or $\mathrm{RuO}_{2}$, quantitative XRD measurements were also conducted. A whole pattern Rietveld least squared refinement was conducted on samples using $10 \mathrm{wt} \%$ high purity alumina as an internal intensity standard. The Archimedes method was used to measure the density of the 
original glass ${ }^{17}$ and standard densities of the crystalline phases were referenced. Once both densities were determined, total volume percent crystallinity was calculated.

\subsection{Product Consistency Test}

The ASTM procedure C1285, PCT Method-A, ${ }^{18}$ was performed in triplicate on each isothermally heat treated, quenched and CCC glass to assess chemical durability. Also included in the experimental test matrix was the Environmental Assessment (EA) benchmark glass, ${ }^{19}$ the Approved Reference Material (ARM) glass and blanks from the sample cleaning batch. Samples were ground, washed and prepared following the standard procedure. ${ }^{18}$ Approximately fifteen milliliters of Type I ASTM water were added to $1.5 \mathrm{~g}$ of glass in stainless steel vessels. The vessels were closed, sealed and placed into an oven at $90 \pm 2{ }^{\circ} \mathrm{C}$ where the samples were maintained at temperature for 7 days \pm 3.4 hours. Once cooled, the resulting solutions were sampled (filtered and acidified), then labeled and analyzed by PSAL under the auspices of an analytical plan. ${ }^{20}$ The resulting solutions (leachates) were analyzed via ICP-AES for Si, B, Na, and $\mathrm{Li}$ release. Samples of a multi-element, standard solution were also included in the analytical plans as a check on the accuracy of the analytical instrumentation used for these measurements. Normalized release rates were calculated based measured compositions using the average of the common logarithms of the leachate concentrations.

\subsection{Results and Discussion}

\subsection{Chemical Compositions}

The targeted and measured composition of the final glass caches, which were used for heat treatments are found in Table 3-1. No significant discrepancies were found between the targeted and analyzed compositions. This indicates the batching was successful and any sample taken from the glass cache will be representative of the measured composition. For a more detailed description of the statistical analysis of the glass batches, see the referenced report by Edwards. ${ }^{14}$ 
SRNL-STI-2010-00373

Revision 0

Table 3-1. Target and Overall Measured Concentrations by Weight Percent Oxide for the Cache of C2-510 and C4-418 Glass ${ }^{14}$

\begin{tabular}{|c|c|c|c|c|}
\hline \multirow[t]{2}{*}{ Oxide } & \multicolumn{2}{|c|}{$\begin{array}{l}\text { C2-510 (Cluster } 2 \\
\text { with Frit 510) }\end{array}$} & \multicolumn{2}{|c|}{$\begin{array}{c}\text { C4-418 (Cluster } 4 \text { with } \\
\text { Frit 418) }\end{array}$} \\
\hline & Target & Measured* & Target & Measured $^{+}$ \\
\hline $\mathrm{Al}_{2} \mathrm{O}_{3}$ & 8.55 & 8.51 & 6.02 & 6.00 \\
\hline $\mathrm{B}_{2} \mathrm{O}_{3}$ & 9.24 & 9.17 & 4.96 & 4.84 \\
\hline $\mathrm{BaO}$ & 0.08 & 0.07 & 0.10 & 0.10 \\
\hline $\mathrm{CaO}$ & 0.97 & 1.01 & 1.34 & 1.32 \\
\hline $\mathrm{Ce}_{2} \mathrm{O}_{3}$ & 0.21 & 0.20 & 0.24 & 0.23 \\
\hline $\mathrm{Cr}_{2} \mathrm{O}_{3}$ & 0.10 & 0.10 & 0.14 & 0.13 \\
\hline $\mathrm{CuO}$ & 0.03 & 0.04 & 0.04 & 0.05 \\
\hline $\mathrm{Fe}_{2} \mathrm{O}_{3}$ & 11.41 & 11.30 & 14.48 & 14.08 \\
\hline $\mathrm{K}_{2} \mathrm{O}$ & 0.07 & 0.07 & 0.09 & 0.10 \\
\hline $\mathrm{La}_{2} \mathrm{O}_{3}$ & 0.07 & 0.07 & 0.09 & 0.08 \\
\hline $\mathrm{Li}_{2} \mathrm{O}$ & 5.28 & 5.22 & 4.96 & 4.89 \\
\hline $\mathrm{MgO}$ & 0.15 & 0.15 & 0.19 & 0.20 \\
\hline $\mathrm{MnO}$ & 1.48 & 1.46 & 2.13 & 2.13 \\
\hline $\mathrm{Na}_{2} \mathrm{O}$ & 12.78 & 12.71 & 13.69 & 13.33 \\
\hline $\mathrm{NiO}$ & 0.43 & 0.40 & 0.53 & 0.49 \\
\hline $\mathrm{PbO}$ & 0.09 & 0.08 & 0.11 & 0.10 \\
\hline $\mathrm{RuO}_{2}$ & 0.10 & 0.04 & 0.10 & 0.04 \\
\hline $\mathrm{SiO}_{2}$ & 47.44 & 46.48 & 49.22 & 48.16 \\
\hline $\mathrm{SO}_{4}{ }^{2-}$ & 0.07 & 0.10 & 0.10 & 0.13 \\
\hline $\mathrm{TiO}_{2}$ & 1.22 & 1.17 & 1.14 & 1.09 \\
\hline $\mathrm{ZnO}$ & 0.05 & 0.05 & 0.07 & 0.06 \\
\hline $\mathrm{ZrO}_{2}$ & 0.19 & 0.18 & 0.25 & 0.25 \\
\hline Sum & 100.00 & 98.58 & 100.00 & 97.79 \\
\hline
\end{tabular}

* The measured composition is an average of the measured compositions of batches A-E

+ The measured composition is an average of the measured compositions of batches A-F

\subsection{Glass Transition Temperatures}

The glass transition onset temperature was measured using DSC. The onset of $\mathrm{T}_{\mathrm{g}}$ for C2-510 glass was determined to occur at $452 \pm 0.2{ }^{\circ} \mathrm{C}$. The onset of $\mathrm{T}_{\mathrm{g}}$ for the C4-418 glass was determined to occur at $448 \pm 1{ }^{\circ} \mathrm{C}$. The $\mathrm{T}_{\mathrm{g}}$ is an indicator of the approximate temperature where the supercooled liquid converts to a solid on cooling or conversely, where the solid begins to behave as a viscoelastic solid on heating. This is extremely important because crystallization cannot occur below the onset of $\mathrm{T}_{\mathrm{g}}$. The $\mathrm{T}_{\mathrm{g}}$ of the current glasses are also similar to the measured glass transition ranges for the seven WCP glasses and the SB3-Frit 418 glass. The glass transition range for the WCP glasses were between $418{ }^{\circ} \mathrm{C}$ and $460{ }^{\circ} \mathrm{C}$ and the SB3-Frit 418 glass had a $\mathrm{T}_{\mathrm{g}}$ of $443{ }^{\circ} \mathrm{C} .{ }^{3,21}$ Measured glass transition temperatures of $448{ }^{\circ} \mathrm{C}$ and $452{ }^{\circ} \mathrm{C}$ also satisfies the requirement for glass stability as stated in the WCP and is above the lower limit of $400{ }^{\circ} \mathrm{C}^{22}$ 


\subsection{Phase Analysis (XRD Qualitative and Quantitative)}

$\mathrm{XRD}$ was completed on every heat treated sample as well as quenched and CCC heat treated samples. Table 3-2 lists the results of the XRD analysis on the C2-510 glass samples and Table 3-3 lists the results of the XRD results of the C4-418 glass samples. Extensively more crystallization was observed in these glass compositions as compared to the crystallization observed in the SB3-Frit 418 TTT study. ${ }^{3}$ Ruthenium oxide $\left(\mathrm{RuO}_{2}\right)$ was observed in almost every sample. This is due to the higher additions of $\mathrm{RuO}_{2}$, which is not soluble into a borosilicate glass composition. ${ }^{7}$ Because of the elevated amount of $\mathrm{RuO}_{2}$ more nucleation sites are bound to be present which will cause more crystallization sites. Often $\mathrm{RuO}_{2}$ will initiate crystallization of a spinel type crystal such as trevorite. This was observed extensively in both glass compositions. Trevorite was formed in the CCC glasses and at times as short as one hour at higher temperatures $\left(>900^{\circ} \mathrm{C}\right)$. This is also consistent with what was observed in the WCP glasses. ${ }^{2}$

Other extensive crystallization occurred with more extended durations of heat treatment time (24 hours and longer) at temperatures between $500{ }^{\circ} \mathrm{C}$ and $700{ }^{\circ} \mathrm{C}$. Phases that were detected in both glasses included phases which could potentially affect the durability of the residual glass such as nepheline $\left(\mathrm{NaAlSiO}_{4}\right)$ and lithium metasilicate $\left(\mathrm{Li}_{2} \mathrm{SiO}_{3}\right)$. The time and temperature at which these durability affecting phases are forming in the current glass systems are consistent with the diagrams of the HM and Blend compositions covered by the WCP TTT study. ${ }^{2}$ Sodium transition metal silicate-based phases such as aegirine $\left(\mathrm{NaFe}^{3+}\left(\mathrm{SiO}_{3}\right)_{2}\right)$ (which is synonymous to acmite), and spinel structured phases such trevorite $\left(\mathrm{NiFe}_{2} \mathrm{O}_{4}\right)$, magnetite $\left(\mathrm{Fe}^{2+} \mathrm{Fe}_{2}{ }^{3+} \mathrm{O}_{4}\right)$, and hematite $\left(\mathrm{Fe}_{2} \mathrm{O}_{3}\right)$ formed in both glasses, but are not expected to exhibit a significant decrease in durability for the remaining glass.

Glass C2-510 had a single new phase, which was not detected in previous TTT studies. This phase detected was calcium magnesium iron silicon oxide $\left(\mathrm{Ca}_{4}\left(\mathrm{Mg}_{4.9} \mathrm{Fe}_{8.7} \mathrm{Si}_{10.4}\right) \mathrm{O}_{40}\right)$. Krinovite $\left(\mathrm{NaMg}_{2} \mathrm{CrSi}_{3} \mathrm{O}_{10}\right)$ was again observed in one specific time and temperature sample as it was in the SB3-Frit 418 TTT glass. It was observed at the temperature of $600{ }^{\circ} \mathrm{C}$. These alkaline earth iron/chromium silicate phases were hard to identify due to the complex XRD pattern and overlapping peaks when phases such as nepheline, hematite and lithium silicate were present. 
Table 3-2. Crystalline Phases of the Heat Treated Sample Detected With X-ray Diffraction for C2-510 Glass

\begin{tabular}{|c|c|c|c|}
\hline Sample & Phases & Sample & Phases \\
\hline C2-1000-1 & $\mathrm{RuO}_{2}$ & $\mathrm{C} 2-800-96$ & Trevorite, $\mathrm{RuO}_{2}$ \\
\hline $\mathrm{C} 2-1000-3$ & $\mathrm{RuO}_{2}$ & $\mathrm{C} 2-800-192$ & Trevorite, $\mathrm{RuO}_{2}$ \\
\hline $\mathrm{C} 2-1000-6$ & $\mathrm{RuO}_{2}$ & $\mathrm{C} 2-800-384$ & Trevorite, $\mathrm{RuO}_{2}$ \\
\hline $\mathrm{C} 2-1000-12$ & $\mathrm{RuO}_{2}$ & $\mathrm{C} 2-800-768$ & Trevorite, $\mathrm{RuO}_{2}$ \\
\hline $\mathrm{C} 2-1000-24$ & $\mathrm{RuO}_{2}$ & $\mathrm{C} 2-700-6$ & Trevorite \\
\hline C2-1000-48 & $\mathrm{RuO}_{2}$ & $\mathrm{C} 2-700-12$ & Trevorite \\
\hline $\mathrm{C} 2-1000-96$ & $\mathrm{RuO}_{2}$ & $\mathrm{C} 2-700-24$ & Trevorite \\
\hline C2-1000-192 & $\mathrm{RuO}_{2}$ & $\mathrm{C} 2-700-48$ & Trevorite \\
\hline C2-1000-384 & $\mathrm{RuO}_{2}$ & $\mathrm{C} 2-700-96$ & Aegirine, Trevorite \\
\hline C2-1000-768 & $\mathrm{RuO}_{2}$ & $\mathrm{C} 2-700-192$ & Aegirine \\
\hline C2-900-1 & Trevorite, $\mathrm{RuO}_{2}$ & $\mathrm{C} 2-700-384$ & Aegirine, Lithium Silicate \\
\hline C2-900-3 & Trevorite, $\mathrm{RuO}_{2}$ & $\mathrm{C} 2-700-768$ & Aegirine, Lithium Silicate \\
\hline C2-900-6 & Trevorite, $\mathrm{RuO}_{2}$ & $\mathrm{C} 2-600-12$ & Amorphous \\
\hline $\mathrm{C} 2-900-12$ & Trevorite, $\mathrm{RuO}_{2}$ & $\mathrm{C} 2-600-24$ & Trevorite \\
\hline $\mathrm{C} 2-900-24$ & Trevorite, $\mathrm{RuO}_{2}$ & $\mathrm{C} 2-600-48$ & $\mathrm{RuO}_{2}$, Krinovite \\
\hline C2-900-48 & Trevorite, $\mathrm{RuO}_{2}$ & C2-600-96 & $\begin{array}{l}\text { Nepheline, Calcium Magnesium Iron Silicon } \\
\text { Oxide, Hematite }\end{array}$ \\
\hline C2-900-96 & Trevorite, $\mathrm{RuO}_{2}$ & C2-600-192 & $\begin{array}{c}\text { Nepheline, Calcium Magnesium Iron Silicon } \\
\text { Oxide, Hematite, Lithium Silicate }\end{array}$ \\
\hline C2-900-192 & Trevorite, $\mathrm{RuO}_{2}$ & C2-600-384 & $\begin{array}{c}\text { Nepheline, Calcium Magnesium Iron Silicon } \\
\text { Oxide, Aegirine, Lithium Silicate }\end{array}$ \\
\hline C2-900-384 & Trevorite, $\mathrm{RuO}_{2}$ & C2-600-768 & $\begin{array}{c}\text { Nepheline, Calcium Magnesium Iron Silicon } \\
\text { Oxide, Aegirine, Lithium Silicate }\end{array}$ \\
\hline C2-900-768 & Trevorite, $\mathrm{RuO}_{2}$ & $\mathrm{C} 2-500-24$ & Amorphous \\
\hline $\mathrm{C} 2-800-3$ & Trevorite & $\mathrm{C} 2-500-48$ & $\mathrm{RuO}_{2}$ \\
\hline $\mathrm{C} 2-800-6$ & Trevorite & $\mathrm{C} 2-500-96$ & $\mathrm{RuO}_{2}$ \\
\hline $\mathrm{C} 2-800-12$ & Trevorite & $\mathrm{C} 2-500-192$ & $\mathrm{RuO}_{2}$ \\
\hline $\mathrm{C} 2-800-24$ & Trevorite & $\mathrm{C} 2-500-384$ & $\mathrm{RuO}_{2}$ \\
\hline $\mathrm{C} 2-800-48$ & Trevorite & $\mathrm{C} 2-500-768$ & Nepheline \\
\hline C2-quenched & $\mathrm{RuO}_{2}$ & $\mathrm{C} 2-\mathrm{CCC}$ & Trevorite \\
\hline
\end{tabular}


Table 3-3 Crystalline Phases of the Heat Treated Sample Detected With X-ray Diffraction for C4-418 Glass

\begin{tabular}{|c|c|c|c|}
\hline Sample & Phases & Sample & Phases \\
\hline C4-1000-1 & Trevorite & C4-800-192 & Trevorite/Magnetite \\
\hline C4-1000-3 & Trevorite & C4-800-384 & Trevorite/Magnetite \\
\hline C4-1000-6 & Trevorite & C4-800-768 & Trevorite/Magnetite \\
\hline C4-1000-12 & Amorphous & $\mathrm{C} 4-700-6$ & Trevorite/Magnetite \\
\hline C4-1000-24 & Amorphous & C4-700-12 & Trevorite/Magnetite \\
\hline C4-1000-48 & Amorphous & C4-700-24 & Trevorite/Magnetite \\
\hline C4-1000-96 & $\mathrm{RuO}_{2}$ & C4-700-48 & Trevorite/Magnetite \\
\hline C4-1000-192 & Amorphous & C4-700-96 & Trevorite/Magnetite, Aegirine \\
\hline C4-1000-384 & Amorphous & C4-700-192 & Aegirine, Lithium Silicate \\
\hline C4-1000-840 & Amorphous & C4-700-384 & Aegirine, Lithium Silicate \\
\hline C4-900-1 & Trevorite & C4-700-768 & Aegirine, Lithium Silicate \\
\hline C4-900-3 & Trevorite, $\mathrm{RuO}_{2}$ & C4-600-12 & $\mathrm{RuO}_{2}$ \\
\hline C4-900-6 & Trevorite & C4-600-24 & Aegirine \\
\hline C4-900-12 & Trevorite/Magnetite & C4-600-48 & Aegirine, Nepheline, $\mathrm{RuO}_{2}$ \\
\hline C4-900-24 & $\begin{array}{c}\text { Trevorite/Magnetite, } \\
\mathrm{RuO}_{2}\end{array}$ & C4-600-96 & Aegirine, Nepheline, Lithium Silicate \\
\hline C4-900-48 & $\begin{array}{c}\text { Trevorite/Magnetite, } \\
\mathrm{RuO}_{2}\end{array}$ & C4-600-192 & Aegirine, Nepheline, Lithium Silicate \\
\hline C4-900-96 & Trevorite/Magnetite & C4-600-384 & Aegirine, Nepheline, Lithium Silicate \\
\hline C4-900-192 & Trevorite/Magnetite & C4-600-768 & Aegirine, Nepheline, Lithium Silicate \\
\hline C4-900-384 & Trevorite/Magnetite & C4-500-24 & $\mathrm{RuO}_{2}$ \\
\hline C4-900-840 & Trevorite/Magnetite & C4-500-48 & $\mathrm{RuO}_{2}$ \\
\hline C4-800-3 & Trevorite & C4-500-96 & $\mathrm{RuO}_{2}$ \\
\hline C4-800-6 & Trevorite & C4-500-192 & $\mathrm{RuO}_{2}$ \\
\hline C4-800-12 & Trevorite/Magnetite & C4-500-384 & $\mathrm{RuO}_{2}$ \\
\hline C4-800-24 & Trevorite/Magnetite & C4-500-840 & $\mathrm{RuO}_{2}$ \\
\hline C4-800-48 & Trevorite/Magnetite & C4-quenched & $\mathrm{RuO}_{2}$ \\
\hline C4-800-96 & Trevorite/Magnetite & $\mathrm{C} 4-\mathrm{CCC}$ & Trevorite \\
\hline
\end{tabular}

After evaluating the XRD data, TTT diagrams could be developed and are found in Figure 3-1 (for C2-510) and Figure 3-2 (for C4-418). Qualitative phase analysis results were used to determine the preferred regions for crystallization. All heat treated glass samples were plotted on a temperature (in degrees Celsius) versus log time (in hours) graph. Those samples which contained crystals are represented by a shape and color (see key). The phase identification of the CCC glass sample is shown in the upper left and the quenched glass sample is shown in the lower left of the figures for each glass. All samples that remained amorphous, as determined by XRD after the specified treatment temperature and duration are represented by an open circle. The location and arrangement of the crystalline phase data points are used to define the estimated location of the phase transformation region, which indicate the time and temperature where the phase transitions occur. This phase region is outlined by blue dashed lines. The profile of the CCC curve (blue solid lines) is also plotted on the TTT diagrams for reference. 


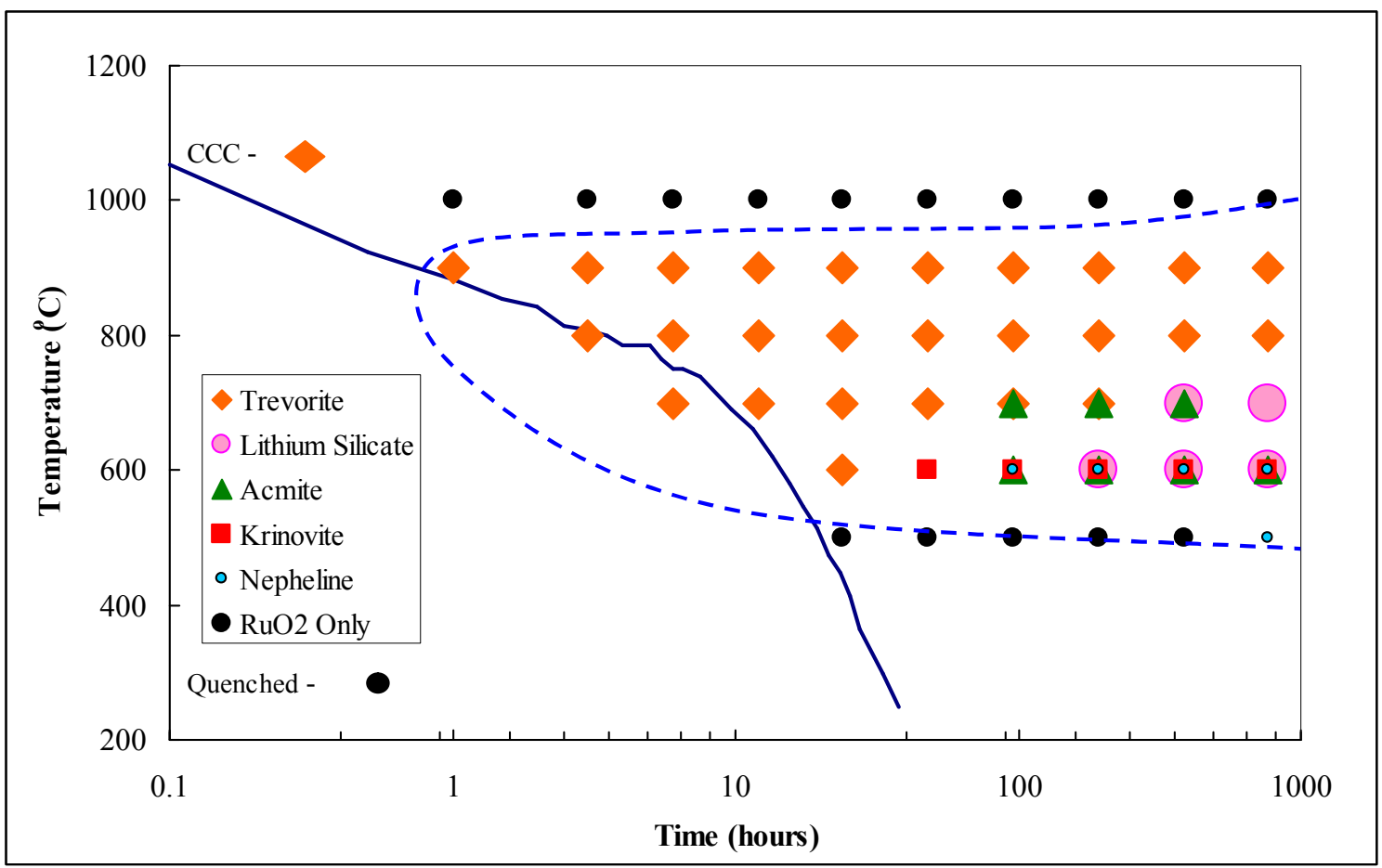

Figure 3-1. TTT diagram for Glass C2-510

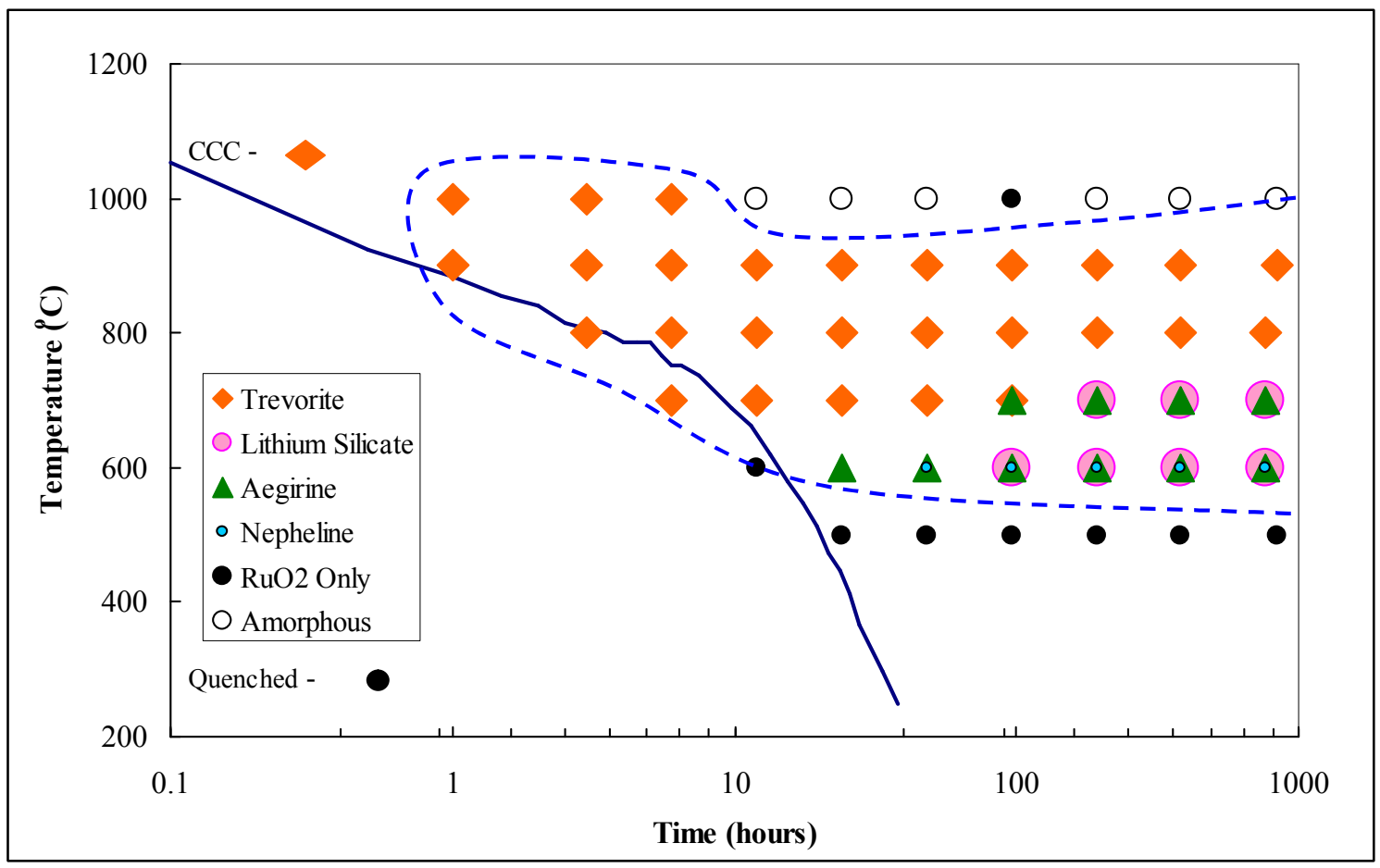

Figure 3-2. TTT diagram for Glass C4-418 
Samples, which contained crystallization in the greatest region of interest $\left(500-700{ }^{\circ} \mathrm{C}\right.$ region), were submitted for quantitative XRD measurements of each of the phases. The results of the quantitative XRD analysis can be found in Table 3-4. In this table, weight percent crystallinity for each phase detected by XRD, as well as weight percent residual phase (the sum of amorphous and minor component fractions), is listed. The quantitative results show that the maximum amount of crystallization for the $\mathrm{C} 2-510$ glass (for those times and temperatures tested) occurred at $600{ }^{\circ} \mathrm{C}$ for 384 hours of treatment. After that duration of treatment, approximately $51.1 \mathrm{wt} \%$ of the sample was crystalline. The quantitative results show that the maximum amount of crystallization for the C4-418 glass (for those times and temperatures tested) occurred at $700{ }^{\circ} \mathrm{C}$ also at 384 hours of treatment. After that duration of treatment, approximately $32.3 \mathrm{wt} \%$ of the sample was crystalline. These results fall in the same temperature and heat treatment time region as the previous SB3-Frit 418 TTT study and the WCP glass study. ${ }^{2,3}$ The greatest amount of crystallization for all DWPF TTT study glasses has occurred at temperatures between $600{ }^{\circ} \mathrm{C}$ and $700^{\circ} \mathrm{C}$ for durations of time $\geq 384$ hours. 
Table 3-4. Quantitative XRD Results for Selected Glasses

\begin{tabular}{|c|c|c|c|c|c|}
\hline Sample & Phases & $\begin{array}{l}\text { Wt \%o } \\
\text { Phase }\end{array}$ & Sample & Phases & $\begin{array}{l}\text { Wt \% } \\
\text { Phase } \\
\end{array}$ \\
\hline \multirow{4}{*}{ C2-600-96 } & Nepheline & 6.4 & \multirow[b]{2}{*}{ C4-600-24 } & Aegirine & 1.2 \\
\hline & $\begin{array}{l}\text { Calcium Magnesium } \\
\text { Iron Silicon Oxide }\end{array}$ & 10.9 & & $\begin{array}{c}\text { Others }+ \\
\text { Amorphous }\end{array}$ & 98.8 \\
\hline & Hematite & 1.4 & \multirow{3}{*}{ C4-600-48 } & Aegirine & 1.6 \\
\hline & Others + Amorphous & 81.3 & & Nepheline & 1.5 \\
\hline \multirow{5}{*}{ C2-600-192 } & Nepheline & 12.8 & & $\begin{array}{c}\text { Others }+ \\
\text { Amorphous }\end{array}$ & 96.9 \\
\hline & $\begin{array}{l}\text { Calcium Magnesium } \\
\text { Iron Silicon Oxide }\end{array}$ & 13.4 & \multirow{4}{*}{ C4-600-96 } & Aegirine & 9.2 \\
\hline & Hematite & 3.6 & & Lithium Silicate & 5.7 \\
\hline & Lithium Silicate & 3.6 & & Nepheline & 5.0 \\
\hline & Others + Amorphous & 66.6 & & $\begin{array}{c}\text { Others }+ \\
\text { Amorphous }\end{array}$ & 80.1 \\
\hline \multirow{5}{*}{ C2-600-384 } & Nepheline & 23.5 & \multirow{4}{*}{ C4-600-192 } & Aegirine & 11.8 \\
\hline & $\begin{array}{l}\text { Calcium Magnesium } \\
\text { Iron Silicon Oxide }\end{array}$ & 18.2 & & Lithium Silicate & 7.5 \\
\hline & Lithium Silicate & 6.4 & & Nepheline & 7.2 \\
\hline & Aegirine & 3.0 & & $\begin{array}{c}\text { Others }+ \\
\text { Amorphous }\end{array}$ & 73.6 \\
\hline & Others + Amorphous & 48.9 & \multirow{4}{*}{ C4-600-384 } & Aegirine & 9.9 \\
\hline \multirow{5}{*}{$C 2-600-768$} & Nepheline & 18.9 & & Lithium Silicate & 6.7 \\
\hline & $\begin{array}{l}\text { Calcium Magnesium } \\
\text { Iron Silicon Oxide }\end{array}$ & 11.8 & & Nepheline & 6.7 \\
\hline & Lithium Silicate & 7.3 & & $\begin{array}{c}\text { Others }+ \\
\text { Amorphous }\end{array}$ & 76.7 \\
\hline & Aegirine & 2.6 & \multirow{4}{*}{ C4-600-840 } & Aegirine & 14.3 \\
\hline & Others + Amorphous & 59.4 & & Lithium Silicate & 9.5 \\
\hline \multirow{3}{*}{$\mathrm{C} 2-500-768$} & Nepheline & 2.2 & & Nepheline & 7.1 \\
\hline & $\mathrm{RuO}_{2}$ & 0.1 & & $\begin{array}{c}\text { Others }+ \\
\text { Amorphous }\end{array}$ & 69.1 \\
\hline & Others + Amorphous & 97.7 & \multirow{3}{*}{ C4-700-96 } & Aegirine & 1.5 \\
\hline \multirow[b]{2}{*}{ C2-700-96 } & Aegirine & 2.7 & & Trevorite & 0.7 \\
\hline & Others + Amorphous & 97.3 & & $\begin{array}{c}\text { Others }+ \\
\text { Amorphous }\end{array}$ & 97.8 \\
\hline \multirow{3}{*}{ C2-700-192 } & Aegirine & 6.4 & \multirow{3}{*}{ C4-700-192 } & Aegirine & 12.7 \\
\hline & Lithium Silicate & 0.7 & & Lithium Silicate & 6.0 \\
\hline & Others + Amorphous & 92.9 & & $\begin{array}{c}\text { Others }+ \\
\text { Amorphous }\end{array}$ & 81.3 \\
\hline \multirow{3}{*}{$\mathrm{C} 2-700-384$} & Aegirine & 14.3 & \multirow{3}{*}{ C4-700-384 } & Aegirine & 21.0 \\
\hline & Lithium Silicate & 3.7 & & Lithium Silicate & 11.3 \\
\hline & Others + Amorphous & 82.0 & & $\begin{array}{c}\text { Others }+ \\
\text { Amorphous }\end{array}$ & 67.7 \\
\hline \multirow{3}{*}{ C2-700-768 } & Aegirine & 14.7 & \multirow{3}{*}{ C4-700-768 } & Aegirine & 20.3 \\
\hline & Lithium Silicate & 4.4 & & Lithium Silicate & 8.8 \\
\hline & Others + Amorphous & 80.9 & & $\begin{array}{c}\text { Others }+ \\
\text { Amorphous }\end{array}$ & 70.9 \\
\hline
\end{tabular}




\subsection{Chemical Durability (PCT Test)}

The normalized releases for all heat treated samples as indicated by the PCT are listed in Table 3-5 and in Table 3-6. The measured PCT response of the reference glasses ARM and EA are also listed in Table 3-7. Tables of measured elemental release of each individual leachate generated by these PCT experiments are listed in Appendix A. The normalized releases are calculated from the measured elemental releases, corrected for dilution and normalized to the concentration of the element in the glass. Based upon the normalized releases for ARM, all of the PCT tests were consistent with previous studies and acceptable according to the ASTM procedure. For the C2510 glass, only one heat treated sample exhibited normalized releases greater than those of EA glass which is $16.695 \mathrm{~g} / \mathrm{L}$ for $\mathrm{B}, 9.565 \mathrm{~g} / \mathrm{L}$ for $\mathrm{Li}, 13.346 \mathrm{~g} / \mathrm{L}$ for Na and $3.922 \mathrm{~g} / \mathrm{L}$ for $\mathrm{Si}^{19}{ }^{19}$ The glass sample heat treated at $600{ }^{\circ} \mathrm{C}$ for 768 hours had normalized releases of $17.335,9.929,7.181$ and $1.774 \mathrm{~g} / \mathrm{L}$ of $\mathrm{B}, \mathrm{Li}, \mathrm{Na}$ and $\mathrm{Si}$ respectively. Based on the XRD results, this sample had approximately $40.6 \mathrm{wt} \%$ overall crystallization of nepheline, aegirine, lithium silicate, and calcium magnesium iron silicon oxide. Presence of the first 3 crystalline phases have all historically been shown to have a negative impact on glass durability as measured by the PCT. ${ }^{2}$ The fourth phase has an unknown direct effect on durability since it is only coincides in these experiments with other durability effecting phases. Keep in mind that this treatment temperature and time are not typical and would even be hard to obtain during an atypical accident scenario. Therefore, PCT results similar to these samples would not be reproducible during normal processing at the DWPF for this glass.

For the C4-418 glass, four heat treated samples exhibited normalized releases greater than those of EA glass. The glass samples heat treated at $600{ }^{\circ} \mathrm{C}$ for $96,192,384$, and 768 hours had B normalized releases of $21.519,44.857,55.533$, and $58.928 \mathrm{~g} / \mathrm{L}$ respectively. Based on the XRD results, these samples had approximately $\geq 20 \mathrm{wt} \%$ overall crystallization of nepheline, aegirine, and lithium silicate. Presence of these crystalline phases have all historically been shown to have a negative impact on glass durability as measured by the PCT. ${ }^{2}$ Keep in mind that this treatment temperature and time are not typical and would even be hard to obtain during an atypical accident scenario. PCT results similar to these samples would not be reproducible during normal processing at the DWPF for this glass either.

To better illustrate the PCT results for both glasses, normalized releases were graphed threedimensionally as a function of heat treatment time and temperature. Figure 3-3 through Figure 3-10 represent the PCT response of the entire heat treated matrix of glass samples for the C2-510 glass. As shown, normalized releases only become elevated at times of 96 hours and longer at temperatures between $600{ }^{\circ} \mathrm{C}$ and $700{ }^{\circ} \mathrm{C}$ and at 768 hours at $500{ }^{\circ} \mathrm{C}$. This also corresponds to the region where non-durable crystalline phases were detected. Figure 3-3 through Figure 3-10 represent the PCT response of the entire heat treated matrix of glass samples for the C4-418 glass. As shown, normalized releases are again only elevated at times of 96 hours and longer at temperatures between $600{ }^{\circ} \mathrm{C}$ and $700{ }^{\circ} \mathrm{C}$. No significant difference in PCT response was seen at $500{ }^{\circ} \mathrm{C}$ for this glass as a function of time. Also, the increase of normalized release for this glass directly corresponds to the region where non-durable crystalline phases such as nepheline and lithium silicate were crystallized. 
Table 3-5. PCT Response of the C2-510 Glass Samples

\begin{tabular}{|c|c|c|c|c|c|c|c|c|c|}
\hline \multirow{2}{*}{ Glass ID } & \multicolumn{4}{|c|}{ NL (g/L) } & \multirow{2}{*}{ Glass ID } & \multicolumn{4}{|c|}{ NL $(g / L)$} \\
\hline & $\mathbf{L i}$ & B & $\mathbf{N a}$ & Si & & $\mathbf{L i}$ & B & $\mathbf{N a}$ & $\mathbf{S i}$ \\
\hline C2-1000-1 & 0.668 & 0.625 & 0.619 & 0.404 & C2-800-768 & 0.650 & 0.576 & 0.622 & 0.440 \\
\hline $\mathrm{C} 2-1000-3$ & 0.658 & 0.629 & 0.630 & 0.396 & $\mathrm{C} 2-700-6$ & 0.635 & 0.558 & 0.634 & 0.427 \\
\hline C2-1000-6 & 0.666 & 0.617 & 0.641 & 0.405 & C2-700-12 & 0.655 & 0.578 & 0.634 & 0.436 \\
\hline C2-1000-12 & 0.637 & 0.587 & 0.605 & 0.392 & C2-700-24 & 0.684 & 0.594 & 0.657 & 0.457 \\
\hline C2-1000-24 & 0.647 & 0.597 & 0.610 & 0.400 & C2-700-48 & 0.664 & 0.573 & 0.629 & 0.443 \\
\hline C2-1000-48 & 0.657 & 0.592 & 0.619 & 0.402 & $\mathrm{C} 2-700-96$ & 0.805 & 0.776 & 0.748 & 0.451 \\
\hline C2-1000-96 & 0.684 & 0.628 & 0.640 & 0.415 & C2-700-192 & 3.087 & 2.334 & 1.645 & 0.818 \\
\hline C2-1000-192 & 0.678 & 0.605 & 0.634 & 0.415 & C2-700-384 & 4.095 & 2.612 & 1.828 & 0.997 \\
\hline C2-1000-384 & 0.671 & 0.586 & 0.640 & 0.420 & $\mathrm{C} 2-700-768$ & 4.196 & 2.732 & 1.866 & 0.999 \\
\hline C2-1000-768 & 0.641 & 0.552 & 0.581 & 0.394 & C2-600-12 & 0.657 & 0.603 & 0.631 & 0.424 \\
\hline C2-900-1 & 0.650 & 0.579 & 0.609 & 0.403 & C2-600-24 & 0.679 & 0.617 & 0.652 & 0.437 \\
\hline C2-900-3 & 0.631 & 0.566 & 0.592 & 0.392 & C2-600-48 & 1.074 & 0.758 & 0.796 & 0.536 \\
\hline C2-900-6 & 0.658 & 0.590 & 0.617 & 0.411 & C2-600-96 & 2.136 & 1.218 & 1.008 & 0.745 \\
\hline C2-900-12 & 0.675 & 0.603 & 0.623 & 0.419 & C2-600-192 & 5.690 & 4.045 & 2.018 & 1.307 \\
\hline C2-900-24 & 0.686 & 0.600 & 0.638 & 0.430 & C2-600-384 & 7.247 & 8.556 & 3.857 & 1.606 \\
\hline C2-900-48 & 0.671 & 0.589 & 0.627 & 0.418 & C2-600-768 & 9.929 & 17.335 & 7.181 & 1.774 \\
\hline C2-900-96 & 0.689 & 0.606 & 0.652 & 0.424 & $\mathrm{C} 2-500-24$ & 0.689 & 0.773 & 0.659 & 0.415 \\
\hline C2-900-192 & 0.669 & 0.597 & 0.621 & 0.418 & C2-500-48 & 0.680 & 0.709 & 0.662 & 0.419 \\
\hline C2-900-384 & 0.696 & 0.603 & 0.651 & 0.432 & $\mathrm{C} 2-500-96$ & 0.682 & 0.699 & 0.676 & 0.415 \\
\hline C2-900-768 & 0.670 & 0.592 & 0.624 & 0.426 & C2-500-192 & 0.837 & 0.867 & 0.762 & 0.458 \\
\hline C2-800-3 & 0.623 & 0.554 & 0.593 & 0.413 & C2-500-384 & 0.988 & 1.098 & 0.857 & 0.496 \\
\hline C2-800-6 & 0.623 & 0.548 & 0.603 & 0.415 & C2-500-768 & 2.435 & 3.037 & 1.691 & 0.783 \\
\hline $\mathrm{C} 2-800-12$ & 0.647 & 0.573 & 0.622 & 0.432 & $\mathrm{C} 2-\mathrm{CCC}$ & 0.674 & 0.575 & 0.617 & 0.422 \\
\hline $\mathrm{C} 2-800-24$ & 0.642 & 0.568 & 0.617 & 0.429 & $\mathrm{C} 2-\mathrm{CCC}$ & 0.652 & 0.578 & 0.604 & 0.434 \\
\hline C2-800-48 & 0.631 & 0.570 & 0.610 & 0.422 & C2-Q & 0.692 & 0.620 & 0.645 & 0.422 \\
\hline $\mathrm{C} 2-800-96$ & 0.663 & 0.589 & 0.632 & 0.439 & C2-Q & 0.664 & 0.607 & 0.621 & 0.430 \\
\hline $\mathrm{C} 2-800-192$ & 0.637 & 0.572 & 0.618 & 0.429 & C2-Q & 0.685 & 0.717 & 0.645 & 0.424 \\
\hline C2-800-384 & 0.631 & 0.556 & 0.617 & 0.426 & & & & & \\
\hline
\end{tabular}


Table 3-6. PCT Response of the C4-418 Glass Samples

\begin{tabular}{|c|c|c|c|c|c|c|c|c|c|}
\hline \multirow{2}{*}{ Glass ID } & \multicolumn{4}{|c|}{ NL (g/L) } & \multirow{2}{*}{ Glass ID } & \multicolumn{4}{|c|}{ NL (g/L) } \\
\hline & $\mathbf{L i}$ & B & $\mathbf{N a}$ & Si & & $\mathbf{L i}$ & B & $\mathrm{Na}$ & $\mathbf{S i}$ \\
\hline C4-1000-1 & 0.971 & 0.908 & 1.060 & 0.597 & C4-800-768 & 0.905 & 0.830 & 1.016 & 0.564 \\
\hline C4-1000-3 & 0.946 & 0.892 & 1.026 & 0.582 & C4-700-6 & 0.913 & 0.910 & 1.021 & 0.556 \\
\hline C4-1000-6 & 0.916 & 0.865 & 0.989 & 0.561 & C4-700-12 & 0.947 & 0.989 & 1.061 & 0.570 \\
\hline C4-1000-12 & 0.961 & 0.921 & 1.074 & 0.598 & C4-700-24 & 0.949 & 0.951 & 1.069 & 0.579 \\
\hline C4-1000-24 & 0.934 & 0.875 & 1.029 & 0.570 & C4-700-48 & 0.978 & 0.846 & 1.085 & 0.582 \\
\hline C4-1000-48 & 0.927 & 0.898 & 1.026 & 0.574 & C4-700-96 & 1.256 & 1.003 & 1.269 & 0.682 \\
\hline C4-1000-96 & 0.932 & 0.875 & 1.012 & 0.579 & C4-700-192 & 3.910 & 1.437 & 1.939 & 1.195 \\
\hline C4-1000-192 & 0.958 & 0.918 & 1.060 & 0.592 & C4-700-384 & 3.936 & 1.476 & 1.953 & 1.213 \\
\hline C4-1000-384 & 0.930 & 0.907 & 1.051 & 0.582 & C4-700-768 & 3.929 & 2.012 & 2.428 & 1.264 \\
\hline C4-1000-840 & 0.900 & 0.772 & 0.954 & 0.526 & C4-600-12 & 0.874 & 1.062 & 0.949 & 0.522 \\
\hline C4-900-1 & 0.939 & 0.859 & 0.979 & 0.575 & C4-600-24 & 0.936 & 1.018 & 1.026 & 0.567 \\
\hline C4-900-3 & 0.956 & 0.897 & 1.055 & 0.591 & C4-600-48 & 1.390 & 1.909 & 1.323 & 0.643 \\
\hline C4-900-6 & 0.900 & 0.817 & 0.997 & 0.550 & C4-600-96 & 7.566 & 21.519 & 9.237 & 2.395 \\
\hline C4-900-12 & 0.923 & 0.839 & 1.006 & 0.567 & C4-600-192 & 9.434 & 44.857 & 16.957 & 3.586 \\
\hline C4-900-24 & 0.894 & 0.820 & 1.015 & 0.557 & C4-600-384 & 10.248 & 55.533 & 20.392 & 4.113 \\
\hline C4-900-48 & 0.886 & 0.823 & 1.016 & 0.564 & C4-600-768 & 10.696 & 58.928 & 21.291 & 4.325 \\
\hline C4-900-96 & 0.894 & 0.855 & 0.995 & 0.552 & C4-500-24 & 1.045 & 1.055 & 1.151 & 0.624 \\
\hline C4-900-192 & 0.896 & 0.833 & 1.024 & 0.574 & C4-500-48 & 0.963 & 0.948 & 1.066 & 0.578 \\
\hline C4-900-384 & 0.859 & 0.790 & 0.967 & 0.540 & C4-500-96 & 0.968 & 0.942 & 1.056 & 0.575 \\
\hline C4-900-840 & 0.857 & 0.800 & 0.960 & 0.535 & C4-500-192 & 1.002 & 0.991 & 1.107 & 0.601 \\
\hline C4-800-3 & 0.973 & 0.894 & 1.076 & 0.589 & C4-500-384 & 1.137 & 1.141 & 1.192 & 0.648 \\
\hline C4-800-6 & 0.953 & 0.876 & 1.064 & 0.581 & C4-500-840 & 1.151 & 1.128 & 1.134 & 0.634 \\
\hline C4-800-12 & 1.009 & 0.927 & 1.133 & 0.611 & $\mathrm{C} 4-\mathrm{CCC}$ & 0.896 & 0.803 & 0.914 & 0.546 \\
\hline C4-800-24 & 0.980 & 0.902 & 1.100 & 0.593 & $\mathrm{C} 4-\mathrm{CCC}$ & 0.895 & 0.806 & 0.906 & 0.534 \\
\hline C4-800-48 & 0.963 & 0.886 & 1.089 & 0.589 & C4-Q & 0.958 & 1.087 & 1.052 & 0.574 \\
\hline C4-800-96 & 0.917 & 0.848 & 1.023 & 0.563 & C4-Q & 0.910 & 0.907 & 0.967 & 0.535 \\
\hline C4-800-192 & 0.956 & 0.892 & 1.096 & 0.601 & C4-Q & 0.925 & 0.897 & 0.985 & 0.552 \\
\hline C4-800-384 & 0.934 & 0.863 & 1.077 & 0.580 & & & & & \\
\hline
\end{tabular}

${ }^{\mathrm{a}}$ The sample C4-418 PCT normalized releases were based upon the average of 2 replicates instead of 3.

Table 3-7. PCT Response of the EA and ARM Glass References

\begin{tabular}{||c|c|c|c|c||}
\hline \multirow{2}{*}{$\begin{array}{c}\text { Glass } \\
\text { ID }\end{array}$} & \multicolumn{4}{|c|}{ NL (g/L) } \\
\cline { 2 - 5 } & $\mathbf{L i}$ & $\mathbf{B}$ & $\mathbf{N a}$ & $\mathbf{S i}$ \\
\hline \hline ARM 1 & 0.588 & 0.504 & 0.499 & 0.262 \\
\hline ARM 2 & 0.648 & 0.604 & 0.573 & 0.291 \\
\hline ARM 3 & 0.600 & 0.494 & 0.508 & 0.273 \\
\hline ARM 4 & 0.633 & 0.522 & 0.529 & 0.278 \\
\hline ARM 5 & 0.554 & 0.473 & 0.476 & 0.262 \\
\hline EA 1 & 10.002 & 18.232 & 13.944 & 3.796 \\
\hline EA 2 & 8.089 & 14.309 & 11.182 & 3.385 \\
\hline EA 3 & 10.106 & 20.349 & 13.724 & 3.921 \\
\hline EA 4 & 8.545 & 15.310 & 11.927 & 3.471 \\
\hline EA 5 & 6.101 & 9.477 & 7.576 & 2.529 \\
\hline \hline
\end{tabular}




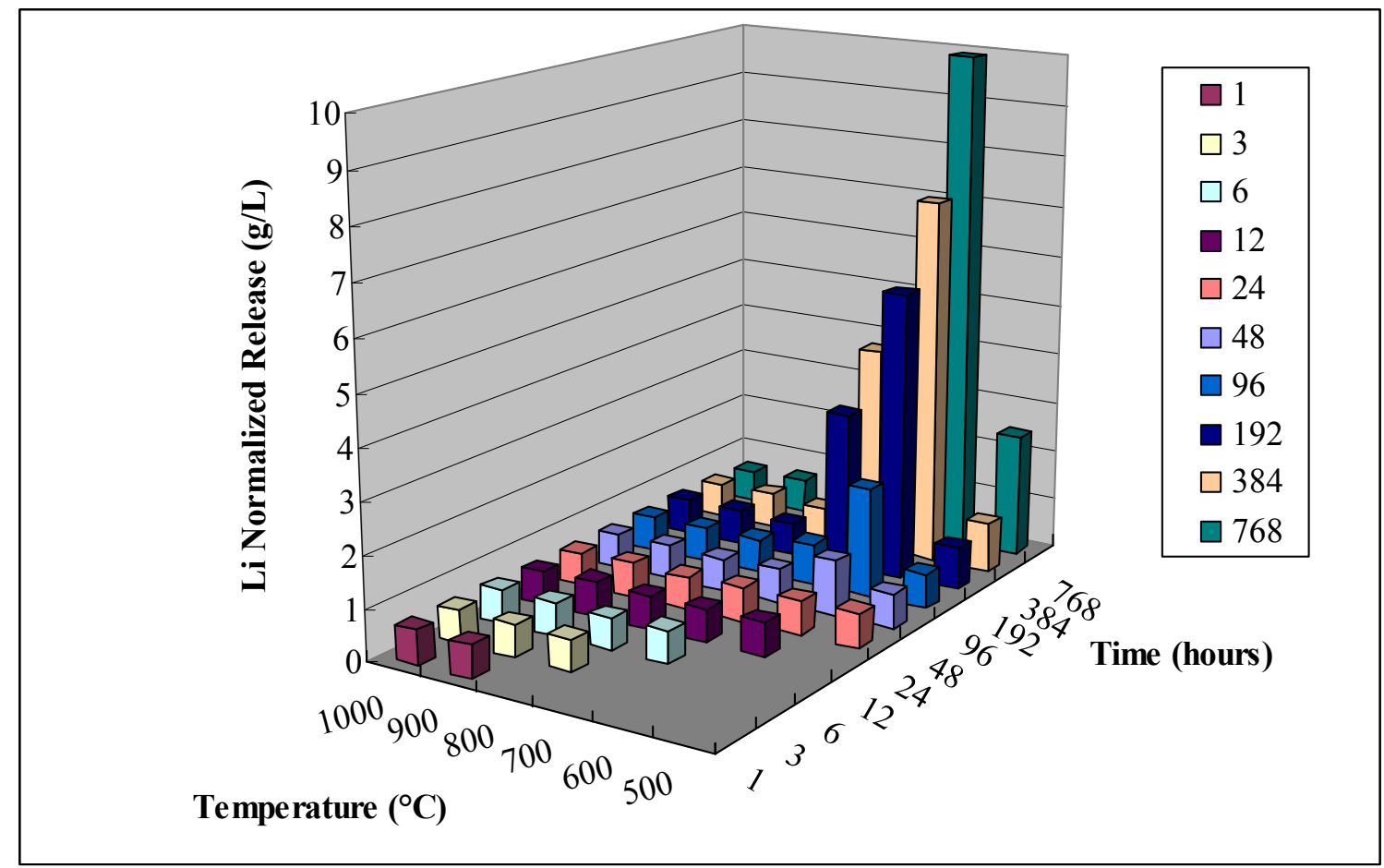

Figure 3-3. Normalized Li Release as a Function of Temperature and Duration of Heat Treatment for the C2-510 Glass Samples

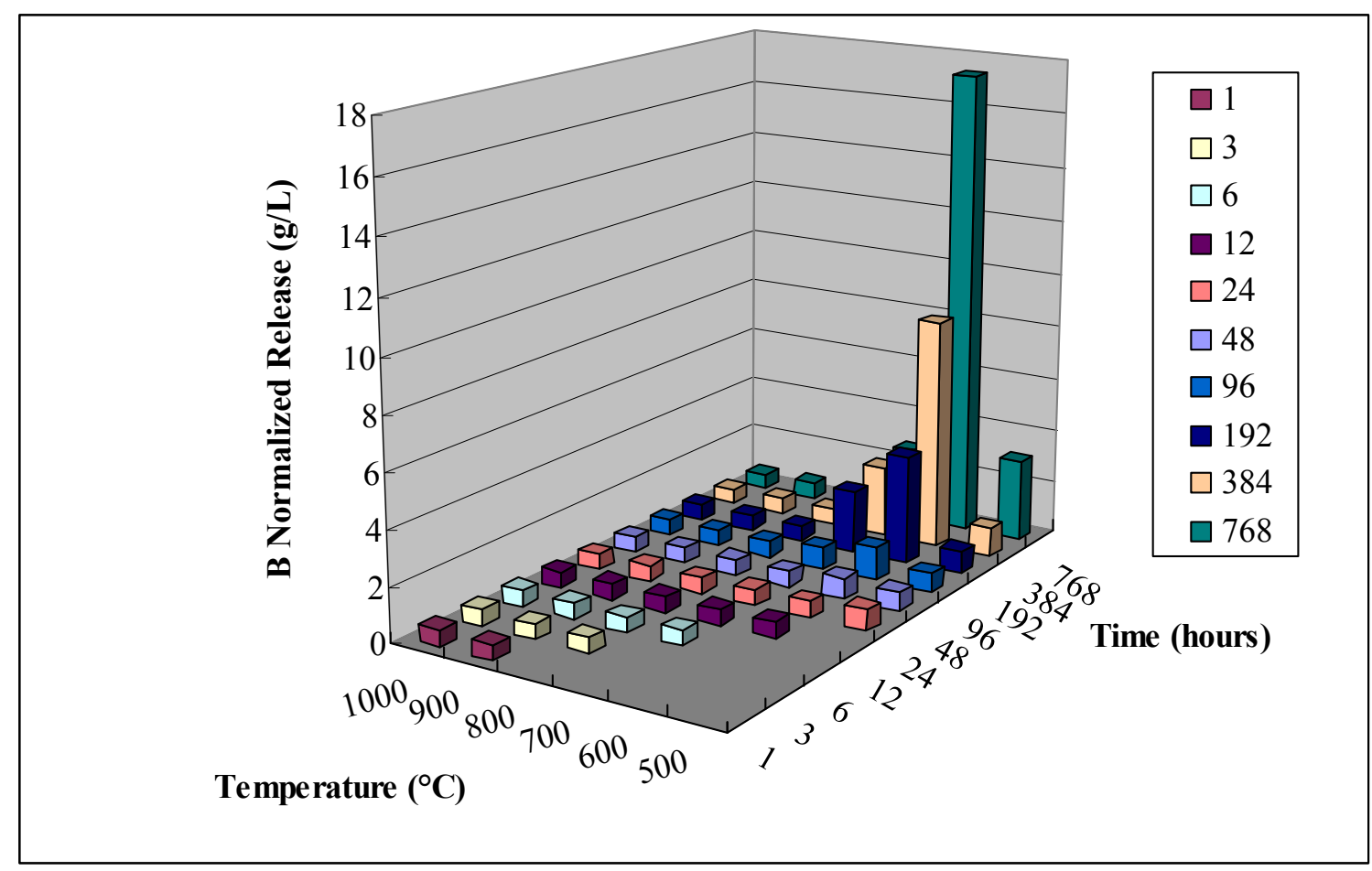

Figure 3-4. Normalized B Release as a Function of Temperature and Duration of Heat Treatment for the C2-510 Glass Samples 


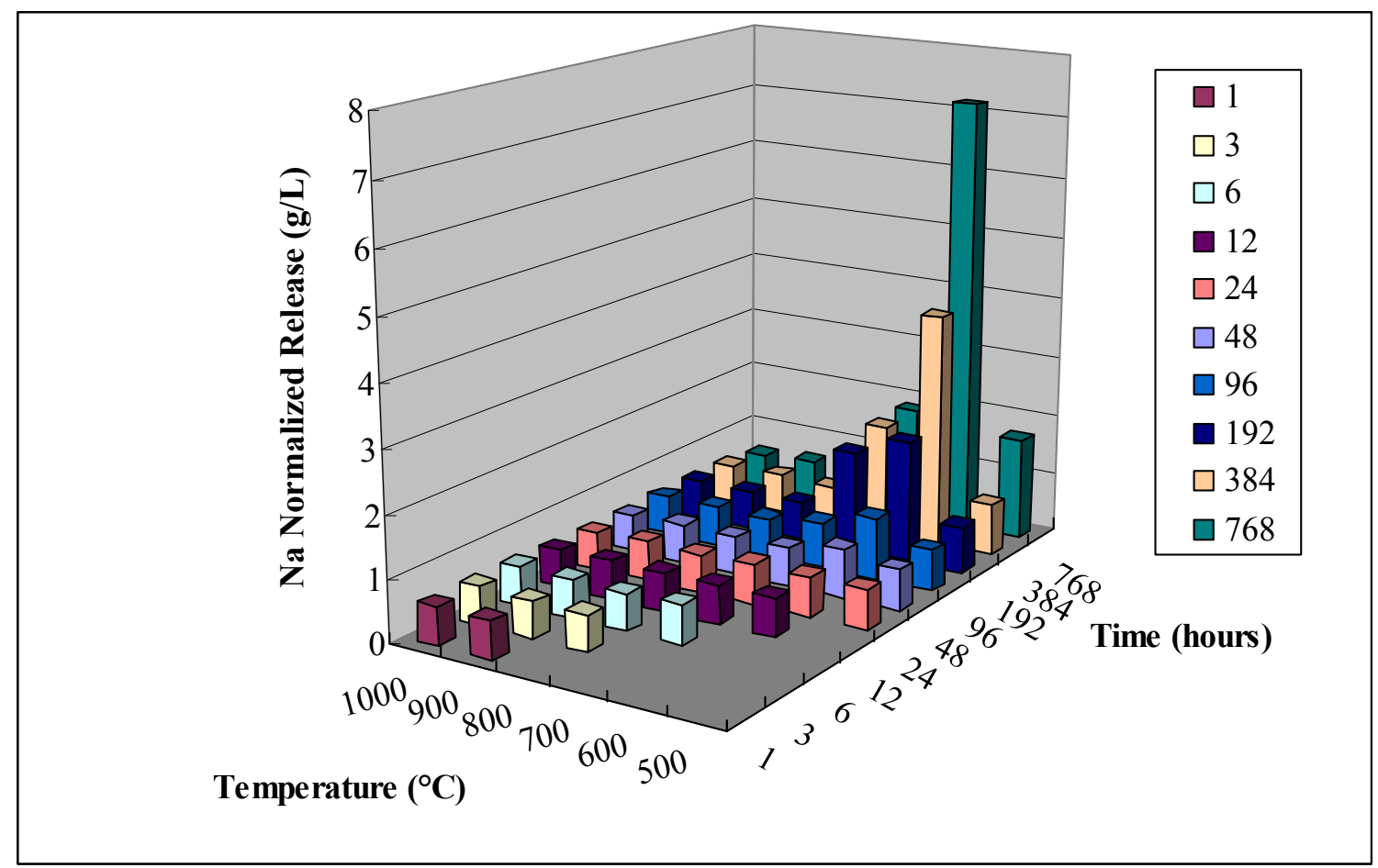

Figure 3-5. Normalized Na Release as a Function of Temperature and Duration of Heat Treatment for the C2-510 Glass Samples

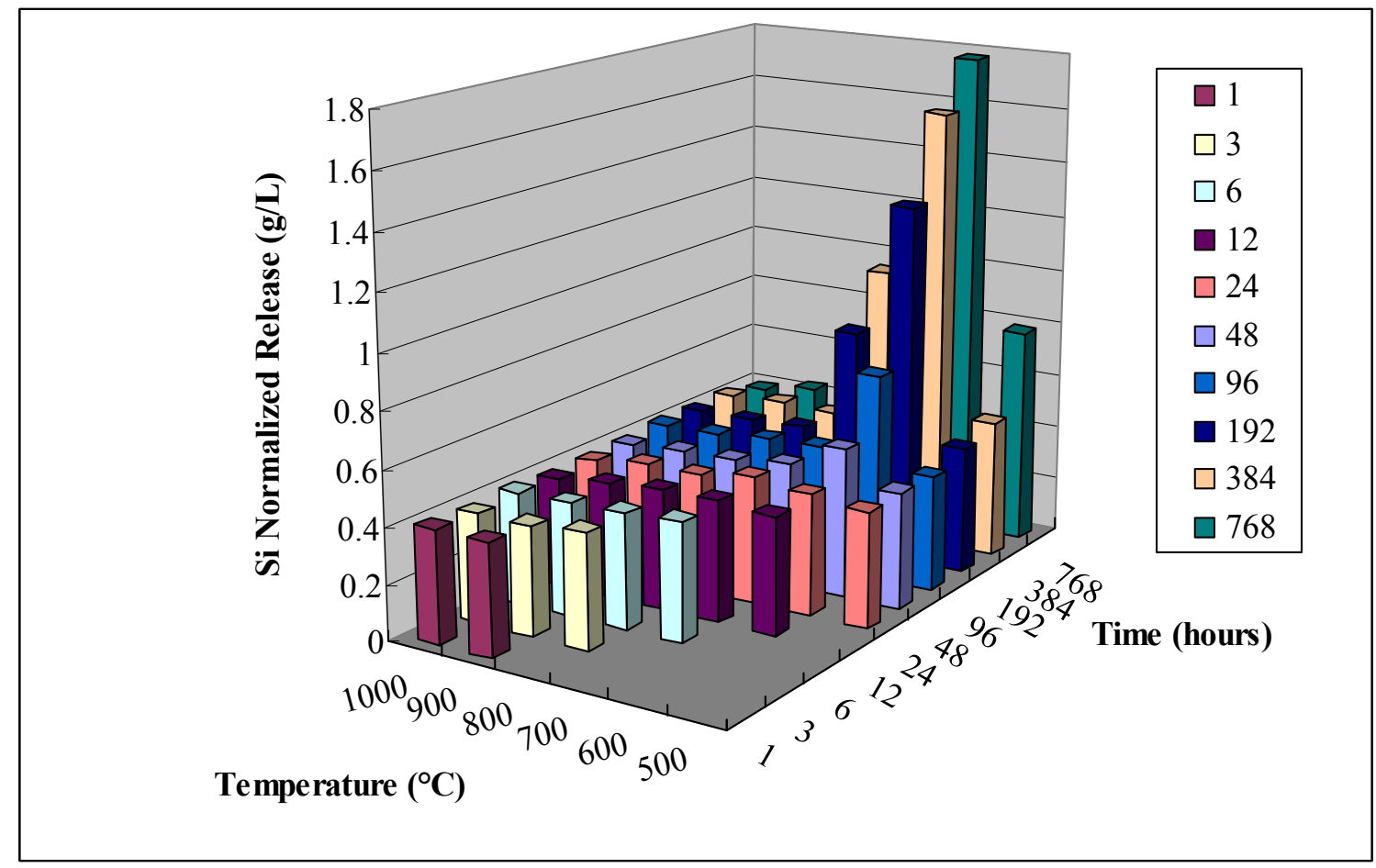

Figure 3-6. Normalized Si Release as a Function of Temperature and Duration of Heat Treatment for the C2-510 Glass Samples 


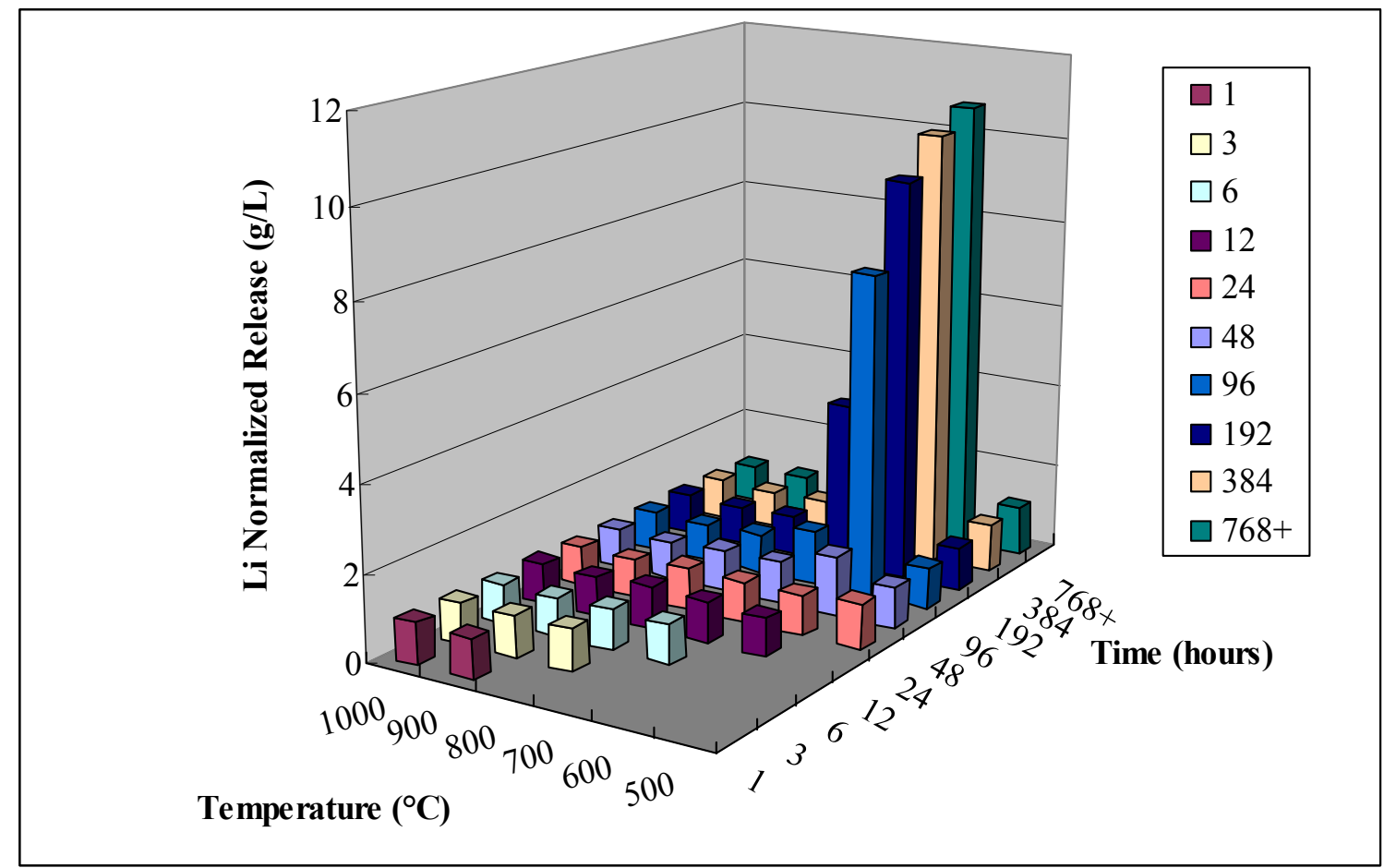

Figure 3-7. Normalized Li Release as a Function of Temperature and Duration of Heat Treatment for the C4-418 Glass Samples

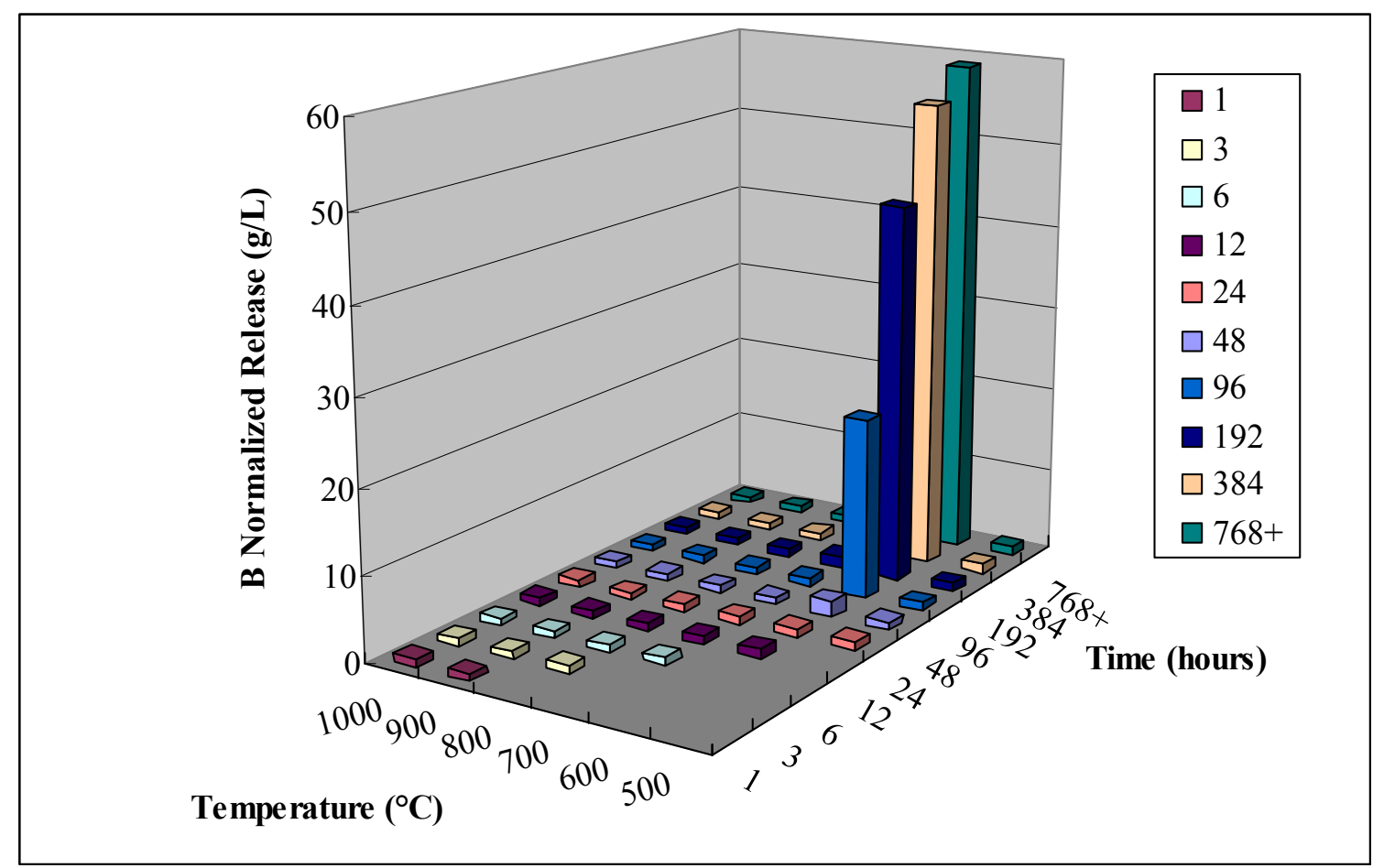

Figure 3-8. Normalized B Release as a Function of Temperature and Duration of Heat Treatment for the C4-418 Glass Samples 


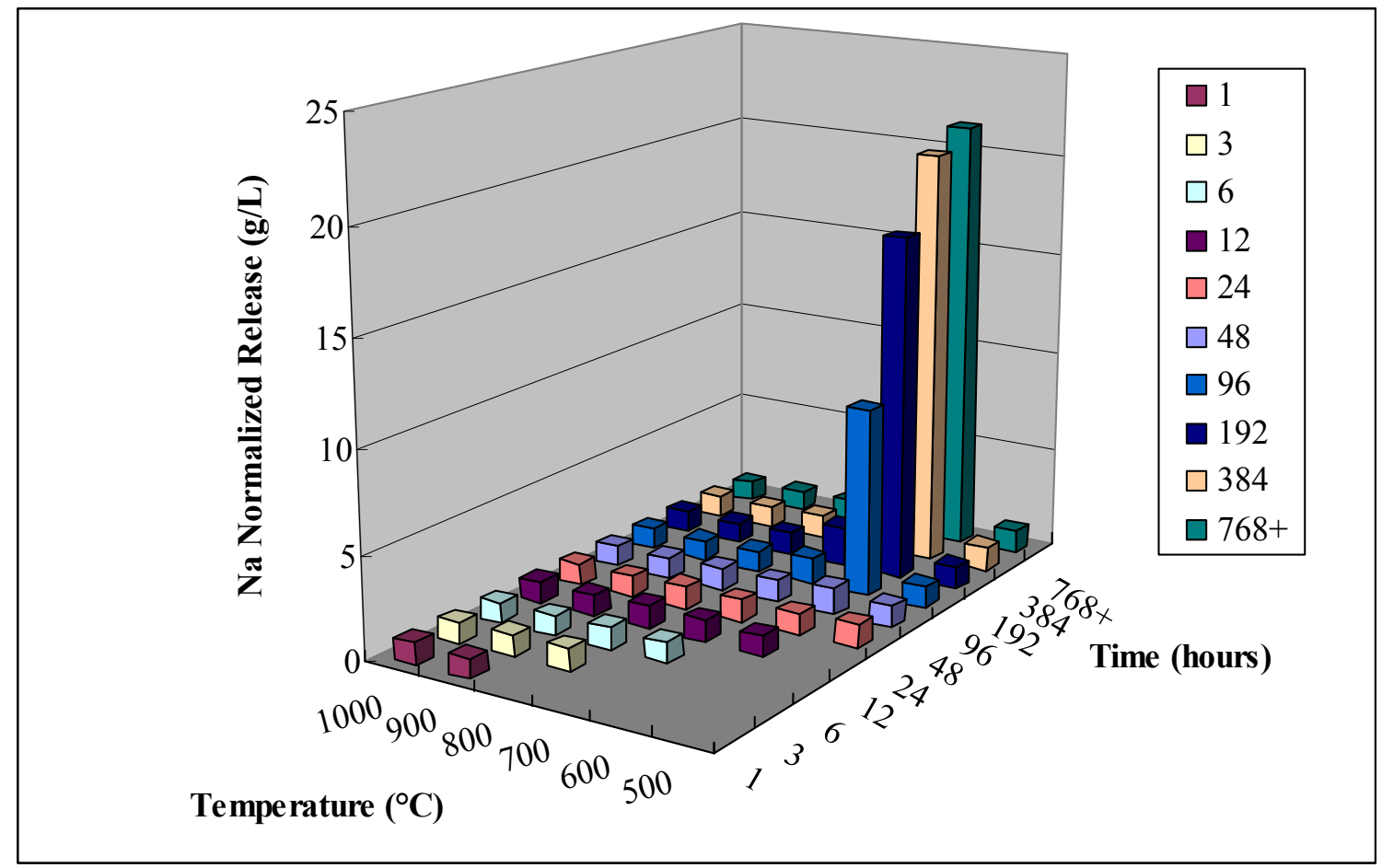

Figure 3-9. Normalized Na Release as a Function of Temperature and Duration of Heat Treatment for the C4-418 Glass Samples

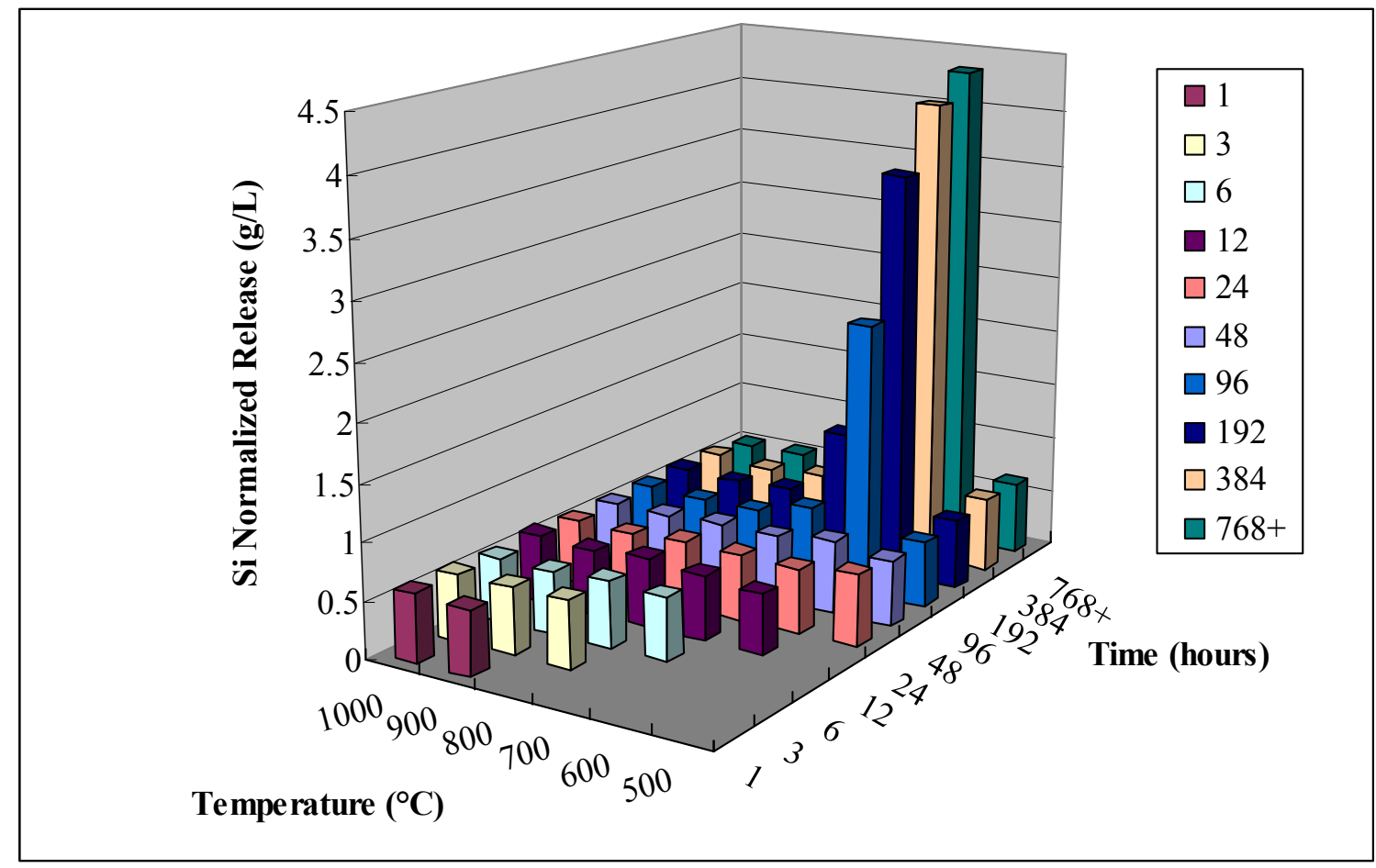

Figure 3-10. Normalized Si Release as a Function of Temperature and Duration of Heat Treatment for the C4-418 Glass Samples 
In order to emphasize the change in PCT response as a function of crystalline phase, Table 3-8 and Table 3-9 list the weight percent crystallinity and phase type parallel to the normalized release of $\mathrm{B}$ for the $\mathrm{C} 2-510$ glass samples and C4-418 glass samples. To illustrate the significance of the identity of the crystalline phase present, compare the normalized B releases for $\mathrm{C} 2-700-96$ and $\mathrm{C} 2-500-768$. For the $\mathrm{C} 2-510$ glass, when aegirine is the only phase present (C2$700-96)$, the normalized B release is low $(0.776 \mathrm{~g} / \mathrm{L})$. Conversely, when approximately the same wt \% of nepheline is present in sample $\mathrm{C} 2-500-768$ the normalized B release is significantly higher $(3.037 \mathrm{~g} / \mathrm{L})$. Those samples, whose normalized B release is elevated, contain higher weight fractions of total crystals and nepheline and/or lithium silicate.

Glass samples of the C4-418 glass exhibit similar behavior relative to the crystallization of nepheline and lithium silicate's effect on normalized B release. For the C4-418 glass, those samples, whose normalized B release is elevated, contain higher weight fractions of total crystals and nepheline and/or lithium silicate present. However, the normalized B release values relative to the quantity of crystalline phase present were significantly higher for this glass as compared to C2-510. For example, the $\mathrm{C} 2-510$ glass sample C2-600-768 contains $18.9 \mathrm{wt} \%$ nepheline and $7.3 \mathrm{wt} \%$ lithium silicate and has a normalized B release of $17.335 \mathrm{~g} / \mathrm{L}$. The C4-418 glass sample C4-600-384 contains lower concentrations of each phase, 6.7 wt \% nepheline and $6.7 \mathrm{wt} \%$ lithium silicate, but has a much higher normalized B release $(55.533 \mathrm{~g} / \mathrm{L})$. This emphasizes the importance of the glass composition. Identity and amount of crystalline phases are important to the durability but often have significantly different tolerances to the weight or volume fraction of each phase which forms. The C4-418 glass composition is significantly more sensitive, with respect to impact on durability, to the presence of small concentrations of durability affecting phases such as nepheline and lithium silicate. 
Table 3-8. Quantitative XRD Results and Normalized B Release for Select Samples of the C2-510 Glass

\begin{tabular}{|c|c|c|c|}
\hline Sample & Phases & $\begin{array}{l}\text { Wt \% } \\
\text { Phase }\end{array}$ & $\begin{array}{c}\text { Normalized } \\
\text { B Release } \\
\text { (g/L) }\end{array}$ \\
\hline \multirow{4}{*}{ C2-600-96 } & Nepheline & 6.4 & \multirow{4}{*}{1.218} \\
\hline & Calcium Magnesium Iron Silicon Oxide & 10.9 & \\
\hline & Hematite & 1.4 & \\
\hline & Others + Amorphous & 81.3 & \\
\hline \multirow{5}{*}{ C2-600-192 } & Nepheline & 12.8 & \multirow{5}{*}{4.045} \\
\hline & Calcium Magnesium Iron Silicon Oxide & 13.4 & \\
\hline & Hematite & 3.6 & \\
\hline & Lithium Silicate & 3.6 & \\
\hline & Others + Amorphous & 66.6 & \\
\hline \multirow{5}{*}{ C2-600-384 } & Nepheline & 23.5 & \multirow{5}{*}{8.556} \\
\hline & Calcium Magnesium Iron Silicon Oxide & 18.2 & \\
\hline & Lithium Silicate & 6.4 & \\
\hline & Aegirine & 3.0 & \\
\hline & Others + Amorphous & 48.9 & \\
\hline \multirow{5}{*}{ C2-600-768 } & Nepheline & 18.9 & \multirow{5}{*}{17.335} \\
\hline & Calcium Magnesium Iron Silicon Oxide & 11.8 & \\
\hline & Lithium Silicate & 7.3 & \\
\hline & Aegirine & 2.6 & \\
\hline & Others + Amorphous & 59.4 & \\
\hline \multirow{3}{*}{ C2-500-768 } & Nepheline & 2.2 & \multirow{3}{*}{3.037} \\
\hline & $\mathrm{RuO}_{2}$ & 0.1 & \\
\hline & Others + Amorphous & 97.7 & \\
\hline \multirow{2}{*}{ C2-700-96 } & Aegirine & 2.7 & \multirow{2}{*}{0.776} \\
\hline & Others + Amorphous & 97.3 & \\
\hline \multirow{3}{*}{ C2-700-192 } & Aegirine & 6.4 & \multirow{3}{*}{2.334} \\
\hline & Lithium Silicate & 0.7 & \\
\hline & Others + Amorphous & 92.9 & \\
\hline \multirow{3}{*}{ C2-700-384 } & Aegirine & 14.3 & \multirow{3}{*}{2.612} \\
\hline & Lithium Silicate & 3.7 & \\
\hline & Others + Amorphous & 82.0 & \\
\hline \multirow{3}{*}{ C2-700-768 } & Aegirine & 14.7 & \multirow{3}{*}{2.732} \\
\hline & Lithium Silicate & 4.4 & \\
\hline & Others + Amorphous & 80.9 & \\
\hline
\end{tabular}


SRNL-STI-2010-00373

Revision 0

Table 3-9. Quantitative XRD Results and Normalized B Release for Select Samples of the C4-418 Glass

\begin{tabular}{|c|c|c|c|}
\hline Sample & Phases & Wt \% Phase & $\begin{array}{c}\text { Normalized } \\
\text { B Release } \\
\text { (g/L) }\end{array}$ \\
\hline \multirow{2}{*}{ C4-600-24 } & Aegirine & 1.2 & \multirow{2}{*}{1.018} \\
\hline & Others + Amorphous & 98.8 & \\
\hline \multirow{3}{*}{ C4-600-48 } & Aegirine & 1.6 & \multirow{3}{*}{1.909} \\
\hline & Nepheline & 1.5 & \\
\hline & Others + Amorphous & 96.9 & \\
\hline \multirow{4}{*}{ C4-600-96 } & Aegirine & 9.2 & \multirow{4}{*}{21.519} \\
\hline & Lithium Silicate & 5.7 & \\
\hline & Nepheline & 5.0 & \\
\hline & Others + Amorphous & 80.1 & \\
\hline \multirow{4}{*}{ C4-600-192 } & Aegirine & 11.8 & \multirow{4}{*}{44.857} \\
\hline & Lithium Silicate & 7.5 & \\
\hline & Nepheline & 7.2 & \\
\hline & Others + Amorphous & 73.6 & \\
\hline \multirow{4}{*}{ C4-600-384 } & Aegirine & 9.9 & \multirow{4}{*}{55.533} \\
\hline & Lithium Silicate & 6.7 & \\
\hline & Nepheline & 6.7 & \\
\hline & Others + Amorphous & 76.7 & \\
\hline \multirow{4}{*}{ C4-600-768 } & Aegirine & 14.3 & \multirow{4}{*}{58.928} \\
\hline & Lithium Silicate & 9.5 & \\
\hline & Nepheline & 7.1 & \\
\hline & Others + Amorphous & 69.1 & \\
\hline \multirow{3}{*}{ C4-700-96 } & Aegirine & 1.5 & \multirow{3}{*}{1.003} \\
\hline & Trevorite & 0.7 & \\
\hline & Others + Amorphous & 97.8 & \\
\hline \multirow{3}{*}{ C4-700-192 } & Aegirine & 12.7 & \multirow{3}{*}{1.437} \\
\hline & Lithium Silicate & 6.0 & \\
\hline & Others + Amorphous & 81.3 & \\
\hline \multirow{3}{*}{ C4-700-384 } & Aegirine & 21.0 & \multirow{3}{*}{1.476} \\
\hline & Lithium Silicate & 11.3 & \\
\hline & Others + Amorphous & 67.7 & \\
\hline \multirow{3}{*}{ C4-700-768 } & Aegirine & 20.3 & \multirow{3}{*}{2.012} \\
\hline & Lithium Silicate & 8.8 & \\
\hline & Others + Amorphous & 70.9 & \\
\hline
\end{tabular}

\subsection{Conclusions}

Two TTT diagrams were completed for simulated waste glasses based on projected future wastes, Cluster 2 - Frit 510 and Cluster 4 - Frit 418. The diagrams were generated using both glass compositions heat treated at various temperatures and durations of time and phase identification using XRD. Types of phases which formed in these two glass systems were similar (if not the same) as has been detected in previous studies. ${ }^{2,3}$ Trevorite, hematite, and magnetite, all spinel based phases, were often found. These phases also occurred when both glasses were treated according to the CCC profile. Aegirine (acmite) also formed frequently in both glasses. In addition, $\mathrm{RuO}_{2}$ was often identified in XRD patterns that contained little to no crystallization 
because $\mathrm{RuO}_{2}$ is insoluble in borosilicate glass systems. Both C2-510 and C4-418 contained 0.10 wt $\% \mathrm{RuO}_{2}$. Major durability affecting crystallization only occurred in the temperature region of $500-700{ }^{\circ} \mathrm{C}$ at times greater than 48 hours. These phases included lithium silicate and nepheline. Also at $600{ }^{\circ} \mathrm{C}$ in the $\mathrm{C} 2-510$ glass, krinovite and calcium magnesium iron silicon oxide was formed, but did not seem to have an independent impact on durability of those samples. Phases and regions of maximum crystallization were within the same crystalline families, if not the same crystals as those previously observed. ${ }^{2,3}$

All glasses of the C2-510 composition, except the glass sample heat treated at $600{ }^{\circ} \mathrm{C}$ for 768 hours had a durability better than that of EA (as measured by the PCT). The aforementioned sample had a normalized B release of $17.335 \mathrm{~g} / \mathrm{L}$ as compared to the accepted normalized $\mathrm{B}$ release of $16.7 \mathrm{~g} / \mathrm{L}$ for EA. ${ }^{19}$ The $\mathrm{C} 4-418$ heat treated glasses had much higher normalized B releases occurring at shorter times at temperatures of $600{ }^{\circ} \mathrm{C} 21.519 \mathrm{~g} / \mathrm{L}$ after 96 hours of treatment and up to $58.928 \mathrm{~g} / \mathrm{L}$ after 768 hours of treatment. The quenched and CCC heat treated samples for both glasses had normalized B releases less than $1.0 \mathrm{~g} / \mathrm{L}$. All other samples had normalized B releases less than EA. Of the matrix of times and temperatures tested, durability effecting crystallization did not occur until far beyond the temperatures and times represented by the CCC curve.

The onset of $\mathrm{T}_{\mathrm{g}}$ for the $\mathrm{C} 2-510$ glass was determined to occur at $452 \pm 0.2{ }^{\circ} \mathrm{C}$. The onset of $\mathrm{T}_{\mathrm{g}}$ for the C4-418 glass was determined to occur at $448 \pm 1{ }^{\circ} \mathrm{C}$. Therefore these glasses will never exhibit a change in morphology below those temperatures, no matter the duration. The $\mathrm{T}_{\mathrm{g}}$ of

these glasses fell within the region of measured temperatures of the WCP glasses and also satisfies the requirement of having a $\mathrm{T}_{\mathrm{g}}$ above $400{ }^{\circ} \mathrm{C} .{ }^{22}$

The data provided in this report supports that these future, average clustered waste compositions will behave similarly to previously studied glasses with respect to phase transformation when treated under abnormal temperature conditions. The conditions imposed on the glass during this study are highly unlikely to occur to any waste glass currently being stored at DWPF.

\subsection{Path Forward}

After years of waste processing and developing TTT diagrams on waste glasses representing various waste types and waste processing strategies, the outcomes are very similar. Compositions of these glasses have spanned a great deal of component variance (see Appendix A for table of compositions). Even after the changes in waste streams, sodium washing and frit development strategies, the phases formed are still the same. Particular crystalline phases will still form in the same temperature and time regions, with the main durability effecting phases (nepheline and lithium silicate) occurring at temperatures between $500{ }^{\circ} \mathrm{C}$ and $700{ }^{\circ} \mathrm{C}$ with the maximum quantity of crystallization likely to occur at $600^{\circ} \mathrm{C}$. Other non-durability affecting phases remain in the same type of crystal families, such as the spinel structures which form in the higher temperature regions but below $\mathrm{T}_{\mathrm{L}}$.

Because of the outstanding similarity in results across great composition variance recommendations for generating future TTT diagrams would be limited to a few select conditions. It is recommended that TTT diagrams only be generated if DWPF would undergo a drastic change in processing strategy that would significantly alter the composition outside of the current region studied. Conditions where this may occur would include a large change in the frit compositions used. A large change in waste loading would also push the glass compositions far outside of the glass compositions currently studied. For example, the highest WL to date in 
which a TTT diagram was generated was 38 wt \%. Waste loadings over 45 wt \% would risk pushing the $\mathrm{Al}, \mathrm{Na}$ and $\mathrm{Fe}$ to significantly higher levels than was previously studied. Another example of an extreme composition change would be the incorporation of a secondary salt or waste stream which could contain much higher levels of minor elements such as Ti. If a significant change in composition is seen or projected, it is recommended that SRNL evaluate whether or not the significant composition change will be likely to change the crystallization kinetics. This could then be confirmed by generating data points in the temperature-time regions of most prevalent crystallization in order to verify similar or dissimilar behavior in phase formation. Full TTT diagrams will only be completed if significant differences in phases or durability response are detected in the confirmatory data points. 


\subsection{References}

1. "Waste Acceptance Product Specification for Vitrified High-Level-Waste Forms," Office of Environmental Management USDOE Document, DOE/EM-0093, Rev. 2, 1996.

2. C.A. Cicero, S.L. Marra, and M.K. Andrews, "Phase Stability Determinations of DWPF Waste Glasses (U)," Westinghouse Savannah River Company, Aiken, SC, WSRC-TR93-00227, Revision 0, May, 1993.

3. A.L. Billings and T.B. Edwards, "Time-Temperature-Transformation (TTT) Diagrams for the Sludge Batch 3 - Frit 418 Glass System," Savannah River National Laboratory, Aiken, SC, SRNL-STI-2009-00025, 2009.

4. A.L. Billings and T.B. Edwards, "Time Temperature Transformation (TTT) Diagrams for Future Waste Types," Savannah River National Laboratory, Aiken, SC, Task Technical \& Quality Assurance Plan, SRNL-RP-2009-00284, 2009.

5. J.W. Ray, "Develop Time Temperature Transformation (TTT) Diagrams for Future Waste Types," DWPF, Aiken, SC, Technical Task Request, HLW-DWPF-TTR-20090006, 2009.

6. J.D. Newell, T.B. Edwards, and D.K. Peeler, "Initial MAR Assessments to Access the Impact of Al-Dissolution on DWPF Operating Windows," Savannah River National Laboratory, Aiken, SC, WSRC-STI-2007-00688, 2007.

7. D.F. Bickford and C.M. Jantzen, "Devitrification of Defense Nuclear Waste Glasses: Role of Melt Insolubles," J. Non-Cryst. Solids, 84 [1-3] 299-307 (1986).

8. "Glass Melting," Savannah River National Laboratory, Aiken, SC, SRTC Procedure Manual, L29, ITS-0003, 2002.

9. "Glass Batching," Savannah River National Laboratory, Aiken, SC, SRTC Procedure Manual, L29, ITS-0001, 2002.

10. $\quad$ "TTT Diagrams Book 2," Savannah River National Laboratory, Aiken, SC, Laboratory Notebook, SRNL-NB-2009-00121, 2009.

11. "TTT Diagrams," Savannah River National Laboratory, Aiken, SC, Laboratory Notebook, WSRC-NB-2006-00074, 2006.

12. T.B. Edwards, "Analytical Plans for Measuring the Chemical Composition of Glass That Is to Be Used for the FY09 TTT Study of Future Waste Types for DWPF," Savannah River National Laboratory, Aiken, SC, Inter-Office Memorandum, SRNL-L5200-2009$00019,2009$.

13. C.M. Jantzen, M.A. Pickett, K.G. Brown, T.B. Edwards, and D.C. Beam, "Process/Product Models for the Defense Waste Processing Facility (DWPF): Part I. Predicting Glass Durability from Composition Using a Thermodynamic Hydration Energy Reaction Model (THERMO)," Savannah River Technology Center, Aiken,SC, WSRC-TR-93-0672, 1993. 
14. T.B. Edwards, "Statistical Review of Chemical Composition Measurements of Glass That Is to Be Used for the TTT Study of Future Waste Types for DWPF," Savannah River National Laboratory, Aiken, SC, Inter-Office Memorandum, SRNL-L5200-2009-00083, 2009.

15. "Standard Test Method for Assignment of the Glass Transition Temperatures by Differential Scanning Calorimetry," American Society for Testing and Materials (ASTM), West Conshohocken, PA, ASTM Standard E 1356, 2003.

16. S.L. Marra and C.M. Jantzen, "Characterization of Projected DWPF Glass Heat Treated to Simulate Canister Centerline Cooling," Westinghouse Savannah River Company, Aiken, SC, WSRC-TR-92-142, Rev. 1, 1993.

17. "Glass Density Using the Mettler AT400 (or Equivalent Balance)," Savannah River National Laboratory, Aiken, SC, SRTC Procedure Manual, L29, ITS-0057, 2006.

18. "Standard Test Methods for Determining Chemical Durability of Nuclear, Hazardous, and Mixed Waste Glasses and Multiphase Glass Ceramics: The Product Consistency Test (PCT)," American Society for Testing and Materials (ASTM), West Conshohocken, PA, ASTM Standard C 1285-02, 2002.

19. C.M. Jantzen, N.E. Bibler, D.C. Beam, C.L. Crawford, and M.A. Pickett, "Characterization of the Defense Waste Processing Facility (DWPF) Environmental Assessment (EA) Glass Standard Reference Material," Savannah River Site, Aiken, SC, WSRC-TR-92-346, Rev. 1, 1994.

20. T.B. Edwards, "Analytical Plans for Measuring the PCT Solutions for the TTT Study Glasses," Savannah River National Laboratory, Aiken, SC, Inter-Office Memorandum, SRNL-L5200-2009-00090, 2009.

21. B.H. Culbertson, S.L. Marra, M.K. Andrews, C.A. Cicero, B.J. Hardy, and M.J. Plodinec, "Phase Stability and Control of the Temperature of the DWPF Product," Savannah River National Laboratory, Aiken, SC, WSRC-IM-91-116-7, Rev. 1, 2006.

22. S.L. Marra and M.J. Plodinec, "DWPF Waste Form Compliance Plan," Savannah River Site, Aiken, SC, USDOE Document WSRC-IM-91-116-0 Rev. 8, March, 2006.

23. C.M. Jantzen, " Research Notebook DPSTN-4155 (E30653)," Savannah River National Laboratory, Aiken, SC, 1984.

24. C.M. Jantzen, " Research Notebook DPSTN-4193 (E35142)," Savannah River National Laboratory, Aiken, SC, 1984. 
SRNL-STI-2010-00373

Revision 0

\section{Appendix A}


Table A-1. Waste Form Compositions of Various Glasses Used to Generate TTT Diagrams, ${ }^{2,22-24}$

\begin{tabular}{|c|c|c|c|c|c|c|c|c|c|c|c|c|c|c|}
\hline $\begin{array}{c}\text { Oxide } \\
\text { (wt \%) }\end{array}$ & $\begin{array}{c}\text { SB3- } \\
\text { Frit } \\
418 \\
\end{array}$ & Blend & HM & Purex & $\begin{array}{c}\text { Batch } \\
\# 1\end{array}$ & $\begin{array}{c}\text { Batch } \\
\# 2\end{array}$ & $\begin{array}{c}\text { Batch } \\
\text { \#3 }\end{array}$ & $\begin{array}{c}\text { Batch } \\
\# 4\end{array}$ & $\begin{array}{c}165 \\
\text { High } \\
\text { Al } \\
\end{array}$ & $\begin{array}{c}165 \mathrm{Av} \\
\text { (TDS) }\end{array}$ & $\begin{array}{c}165 \\
\text { High } \\
\text { Fe } \\
\end{array}$ & $\begin{array}{c}131 \\
\text { High } \\
\text { Al } \\
\end{array}$ & $\begin{array}{c}131 \mathrm{Av} \\
\text { (TDS) }\end{array}$ & $\begin{array}{c}131 \\
\text { High } \\
\text { Fe } \\
\end{array}$ \\
\hline $\mathrm{Al}_{2} \mathrm{O}_{3}$ & ב5.96 & 4.16 & 7.15 & 2.99 & 4.88 & 4.63 & 3.44 & 3.43 & 10.15 & 5.54 & 2.59 & 10.51 & 7.81 & 3.04 \\
\hline $\mathrm{B}_{2} \mathrm{O}_{3}$ & 5.16 & 8.05 & 7.03 & 10.33 & 7.78 & 7.88 & 7.69 & 8.14 & 8.53 & 8.23 & 6.44 & 11.09 & 9.44 & 10.98 \\
\hline $\mathrm{BaO}$ & 0.06 & 0.18 & 0.11 & 0.20 & 0.15 & 0.16 & 0.18 & 0.25 & 0.16 & 0.33 & 0.10 & 0.04 & 0.07 & 0.04 \\
\hline $\mathrm{CaO}$ & 1.13 & 1.03 & 1.01 & 1.09 & 1.22 & 1.08 & 0.99 & 0.84 & 1.42 & 1.67 & 1.14 & 1.49 & 1.56 & 1.63 \\
\hline $\mathrm{Ce}_{2} \mathrm{O}_{3}$ & 0.09 & - & - & - & - & - & - & - & - & - & - & - & - & - \\
\hline $\mathrm{Cr}_{2} \mathrm{O}_{3}$ & 0.09 & 0.13 & 0.09 & 0.15 & 0.11 & 0.13 & 0.14 & 0.14 & 0.19 & 0.19 & 0.14 & 0.17 & 0.20 & 0.19 \\
\hline $\mathrm{Cs}_{2} \mathrm{O}$ & - & 0.08 & 0.06 & 0.06 & 0.06 & 0.02 & 0.06 & 0.09 & 0.00 & 0.03 & 0.03 & 0.03 & 0.03 & 0.03 \\
\hline $\mathrm{CuO}$ & 0.04 & 0.44 & 0.25 & 0.42 & 0.40 & 0.42 & 0.40 & 0.45 & 0.06 & 0.00 & 0.06 & 0.06 & 0.06 & 0.08 \\
\hline $\mathrm{Fe}_{2} \mathrm{O}_{3}$ & 12.75 & 10.91 & 7.78 & 13.25 & 12.84 & 11.12 & 11.71 & 11.71 & 7.53 & 12.14 & 15.52 & 11.36 & 11.44 & 13.52 \\
\hline $\mathrm{K}_{2} \mathrm{O}$ & 0.08 & 3.67 & 2.21 & 3.41 & 3.33 & 3.38 & 3.40 & 3.86 & - & - & - & - & - & - \\
\hline $\mathrm{La}_{2} \mathrm{O}_{3}$ & 0.04 & - & - & - & - & - & - & - & 0.05 & 0.11 & 0.07 & 0.14 & 0.16 & 0.21 \\
\hline $\mathrm{Li}_{2} \mathrm{O}$ & 5.16 & 4.44 & 4.62 & 3.22 & 4.43 & 4.50 & 4.51 & 4.29 & 3.99 & 3.96 & 4.51 & 3.09 & 3.24 & 3.53 \\
\hline $\mathrm{MgO}$ & 1.39 & 1.41 & 1.49 & 1.41 & 1.42 & 1.42 & 1.42 & 1.43 & 0.87 & 0.89 & 0.95 & 1.40 & 1.71 & 1.59 \\
\hline $\mathrm{MnO}$ & 2.59 & 1.67 & 1.75 & 1.69 & 1.72 & 1.41 & 1.53 & 2.54 & 1.45 & 2.08 & 2.71 & 2.39 & 1.96 & 2.59 \\
\hline $\mathrm{Na}_{2} \mathrm{O}$ & 13.88 & 9.13 & 8.56 & 12.62 & 9.00 & 9.21 & 9.01 & 9.16 & 8.48 & 8.26 & 9.88 & 8.90 & 10.89 & 12.29 \\
\hline $\mathrm{Nd}_{2} \mathrm{O}_{3}$ & - & 0.22 & 0.55 & 0.06 & 0.15 & 0.26 & 0.17 & 0.39 & - & - & - & - & - & - \\
\hline $\mathrm{NiO}$ & 0.69 & 0.89 & 0.41 & 1.19 & 0.75 & 0.90 & 1.05 & 1.06 & 0.97 & 1.15 & 1.94 & 0.94 & 1.26 & 1.03 \\
\hline $\mathrm{P}_{2} \mathrm{O}_{5}$ & - & - & - & - & - & - & - & - & 0.14 & 0.16 & 0.09 & 0.12 & 0.14 & 0.13 \\
\hline $\mathrm{PbO}$ & 0.06 & - & - & - & - & - & - & - & 0.26 & 0.35 & 0.51 & 0.42 & 0.43 & 0.46 \\
\hline $\mathrm{RuO}_{2}$ & 0.02 & 0.03 & 0.04 & 0.01 & 0.02 & 0.04 & 0.03 & 0.05 & 0.07 & 0.10 & 0.05 & 0.06 & 0.05 & 0.06 \\
\hline $\mathrm{SiO}_{2}$ & 50.20 & 51.90 & 55.80 & 46.50 & 50.20 & 52.10 & 52.60 & 50.10 & 52.52 & 52.13 & 50.26 & 43.25 & 46.00 & 45.08 \\
\hline $\mathrm{SO}_{4}$ & 0.43 & - & - & - & - & - & - & - & - & - & - & - & - & - \\
\hline $\mathrm{SrO}$ & - & - & - & - & - & - & - & - & 0.05 & 0.05 & 0.08 & 0.05 & 0.06 & 0.05 \\
\hline $\mathrm{ThO}_{2}{ }^{*}$ & - & - & - & - & - & - & - & - & 1.07 & 0.30 & 0.03 & 1.07 & 0.30 & 0.03 \\
\hline $\mathrm{TiO}_{2}$ & 0.01 & 0.89 & 0.56 & 0.68 & 0.68 & 0.69 & 0.68 & 1.03 & 0.07 & 0.07 & 0.16 & 0.72 & 0.75 & 0.74 \\
\hline $\mathrm{U}_{3} \mathrm{O}_{8}$ & & - & - & - & - & - & - & - & 0.91 & 1.13 & 1.91 & 2.16 & 1.93 & 2.11 \\
\hline $\mathrm{ZnO}$ & 0.06 & - & - & - & - & - & - & - & 0.04 & 0.05 & 0.08 & 0.09 & 0.05 & 0.09 \\
\hline $\mathrm{ZrO}_{2}$ & 0.11 & 0.14 & 0.33 & 0.05 & 0.10 & 0.17 & 0.12 & 0.22 & 1.05 & 1.09 & $\begin{array}{c}0.77 \\
\end{array}$ & 0.47 & 0.47 & 0.50 \\
\hline SUM & 100.00 & 99.52 & 100.02 & 99.41 & 99.35 & 99.69 & 99.25 & 99.38 & 100.00 & 100.00 & 100.01 & 100.01 & 100.01 & $\begin{array}{l}100.01 \\
\end{array}$ \\
\hline
\end{tabular}

* $\mathrm{ThO}_{2}$ was calculated from batch compositions. 
Table A-2. Measured Elemental Release of the PCT Leachates of ARM, EA and Blank Samples

\begin{tabular}{|c|c|c|c|c|c|c|c|c|c|c|c|}
\hline \multirow[b]{2}{*}{$\begin{array}{l}\text { Solution } \\
\text { Identifier }\end{array}$} & \multirow[b]{2}{*}{$\begin{array}{c}\text { Original } \\
\text { Sample } \\
\text { ID } \\
\end{array}$} & \multicolumn{4}{|c|}{$\begin{array}{l}\text { Elemental Release from PSAL } \\
(\mathrm{mg} / \mathrm{L})\end{array}$} & \multirow[b]{2}{*}{$\begin{array}{l}\text { Solution } \\
\text { Identifier }\end{array}$} & \multirow[b]{2}{*}{$\begin{array}{c}\text { Original } \\
\text { Sample } \\
\text { ID } \\
\end{array}$} & \multicolumn{4}{|c|}{$\begin{array}{c}\text { Elemental Release from PSAL } \\
(\mathrm{mg} / \mathrm{L})\end{array}$} \\
\hline & & $\mathbf{L i}$ & B & $\mathbf{N a}$ & $\mathbf{S i}$ & & & $\mathbf{L i}$ & B & $\mathbf{N a}$ & $\mathbf{S i}$ \\
\hline D27 & ARM & 8.46 & 10.7 & 20.5 & 34.8 & D24 & EA & 12.3 & 39.7 & 104 & 53.7 \\
\hline D01 & ARM & 8.35 & 10.4 & 22.1 & 33.4 & D73 & EA & 11.8 & 38.5 & 105 & 51.5 \\
\hline D45 & ARM & 8.19 & 10.7 & 21.8 & 34.4 & D29 & EA & 11.5 & 37.0 & 104.4 & 50.5 \\
\hline F58 & ARM & 9.42 & 12.6 & 23.9 & 37.7 & E52 & EA & 9.71 & 30.8 & 85.2 & 46.6 \\
\hline F48 & ARM & 9.21 & 13.5 & 25.1 & 37.8 & E54 & EA & 9.47 & 29.1 & 82.7 & 45.9 \\
\hline F07 & ARM & 8.89 & 12.1 & 25.0 & 38.4 & E18 & EA & 9.64 & 30.5 & 82.9 & 46.3 \\
\hline G57 & ARM & 8.53 & 10.6 & 21.7 & 35.0 & F63 & EA & 12.4 & 41.2 & 101 & 54.3 \\
\hline G67 & ARM & 8.54 & 10.3 & 21.9 & 35.3 & F74 & EA & 11.8 & 45.1 & 103 & 53.9 \\
\hline G15 & ARM & 8.43 & 10.33 & 21.9 & 36.8 & F10 & EA & 11.8 & 42.3 & 104.1 & 52.6 \\
\hline $\mathrm{H} 03$ & ARM & 9.0 & 11.0 & 22.4 & 36.1 & G40 & EA & 10.3 & 32.7 & 92.6 & 48.1 \\
\hline H67 & ARM & 8.86 & 11.1 & 22.9 & 36.5 & G03 & EA & 9.49 & 28.3 & 79.3 & 44.7 \\
\hline H13 & ARM & 9.05 & 10.9 & 22.9 & 36.2 & G28 & EA & 10.6 & 36.2 & 96.7 & 49.7 \\
\hline E65 & ARM & 7.75 & 9.88 & 20.4 & 33.7 & H18 & EA & 7.44 & 20.4 & 57.7 & 35.4 \\
\hline E09 & ARM & 7.84 & 9.80 & 20.5 & 34.4 & H05 & EA & 7.10 & 19.4 & 56.0 & 33.9 \\
\hline E30 & ARM & 7.96 & 10.2 & 20.5 & 34.6 & H57 & EA & 7.20 & 20.0 & 56.4 & 34.5 \\
\hline D44 & Blank & $<0.100$ & 0.416 & $<0.100$ & 1.23 & F13 & Blank & $<0.100$ & $<0.100$ & $<0.100$ & $<0.100$ \\
\hline D05 & Blank & $<1.00$ & 0.847 & $<0.100$ & 0.131 & G24 & Blank & $<0.100$ & $<0.100$ & $<0.100$ & $<0.100$ \\
\hline E28 & Blank & $<0.100$ & $<0.100$ & $<0.100$ & $<0.100$ & G07 & Blank & $<0.100$ & $<0.100$ & $<0.100$ & $<0.100$ \\
\hline E70 & Blank & $<0.100$ & 0.316 & $<0.100$ & $<0.100$ & $\mathrm{H} 74$ & Blank & $<0.100$ & $<0.100$ & 0.166 & $<0.100$ \\
\hline F30 & Blank & $<0.100$ & 0.181 & $<0.100$ & $<0.100$ & $\mathrm{H} 28$ & Blank & $<0.100$ & $<0.100$ & $<0.100$ & $<0.100$ \\
\hline
\end{tabular}


Table A-3. Measured Elemental Results of the ICP Standards

\begin{tabular}{|c|c|c|c|c|c|c|c|c|c|c|c|}
\hline \multirow[b]{2}{*}{$\begin{array}{c}\text { Solution } \\
\text { Identifier }\end{array}$} & \multirow[b]{2}{*}{$\begin{array}{c}\text { Original } \\
\text { Sample ID }\end{array}$} & \multicolumn{4}{|c|}{$\begin{array}{l}\text { Elemental Release from } \\
\text { PSAL }(\mathrm{mg} / \mathrm{L})\end{array}$} & \multirow[b]{2}{*}{$\begin{array}{c}\text { Solution } \\
\text { Identifier }\end{array}$} & \multirow[b]{2}{*}{$\begin{array}{c}\text { Original } \\
\text { Sample ID }\end{array}$} & \multicolumn{4}{|c|}{$\begin{array}{l}\text { Elemental Release from } \\
\text { PSAL }(\mathrm{mg} / \mathrm{L})\end{array}$} \\
\hline & & $\mathbf{L i}$ & B & $\mathbf{N a}$ & $\mathbf{S i}$ & & & $\mathbf{L i}$ & B & $\mathrm{Na}$ & $\mathbf{S i}$ \\
\hline std-11-1 & ICP Standard & 9.91 & 20.7 & 80.4 & 46.5 & std-32-3 & ICP Standard & 10.1 & 21.6 & 85.3 & 49.5 \\
\hline std-11-2 & ICP Standard & 10.2 & 20.1 & 79.9 & 47.6 & std-33-1 & ICP Standard & 9.91 & 21.0 & 84.7 & 49.2 \\
\hline std-11-3 & ICP Standard & 10.0 & 20.0 & 80.9 & 47.0 & std-33-2 & ICP Standard & 10.1 & 20.9 & 85.8 & 48.2 \\
\hline std-12-1 & ICP Standard & 10.0 & 20.7 & 80.7 & 47.1 & std-33-3 & ICP Standard & 10.0 & 21.4 & 84.1 & 47.5 \\
\hline $\begin{array}{l}\text { std-12-2 } \\
\text { std }\end{array}$ & ICP Standard & 10.2 & 19.7 & 83.2 & 46.7 & std-41-1 & ICP Standard & 10.2 & 21.1 & 82.7 & 47.7 \\
\hline std-12-3 & ICP Standard & 10.0 & 19.6 & 80.0 & 47.0 & std-41-2 & ICP Standard & 10.4 & 20.8 & 83.8 & 49.2 \\
\hline std-13-1 & ICP Standard & 9.80 & 21.0 & 80.9 & 47.6 & std-41-3 & ICP Standard & 10.4 & 20.6 & 83.8 & 49.4 \\
\hline std-13-2 & ICP Standard & 10.0 & 19.6 & 86.4 & 46.5 & std-42-1 & ICP Standard & 10.1 & 21.0 & 83.7 & 48.5 \\
\hline std-13-3 & ICP Standard & 9.93 & 19.8 & 83.6 & 47.4 & std-42-2 & ICP Standard & 10.2 & 20.0 & 83.3 & 47.9 \\
\hline std-21-1 & ICP Standard & 9.93 & 21.3 & 84.2 & 49.6 & std-42-3 & ICP Standard & 10.3 & 20.5 & 83.2 & 50.0 \\
\hline std-21-2 & ICP Standard & 9.81 & 20.5 & 82.2 & 48.4 & std-43-1 & ICP Standard & 9.91 & 21.1 & 83.4 & 47.5 \\
\hline std-21-3 & ICP Standard & 9.77 & 20.4 & 82.0 & 48.4 & std-43-2 & ICP Standard & 10.2 & 20.7 & 84.2 & 49.7 \\
\hline std-22-1 & ICP Standard & 9.84 & 20.9 & 82.4 & 49.6 & std-43-3 & ICP Standard & 10.3 & 21.1 & 85.3 & 51.0 \\
\hline std-22-2 & ICP Standard & 9.85 & 20.0 & 82.9 & 49.0 & std-51-1 & ICP Standard & 10.2 & 20.4 & 82.6 & 46.7 \\
\hline std-22-3 & ICP Standard & 9.75 & 19.6 & 82.9 & 48.1 & std-51-2 & ICP Standard & 10.2 & 20.6 & 81.5 & 47.5 \\
\hline std-23-1 & ICP Standard & 9.80 & 20.8 & 81.8 & 49.1 & std-51-3 & ICP Standard & 10.4 & 20.7 & 83.5 & 48.4 \\
\hline std-23-2 & ICP Standard & 9.79 & 20.1 & 82.0 & 48.4 & std-52-1 & ICP Standard & 10.0 & 20.8 & 81.5 & 46.6 \\
\hline std-23-3 & ICP Standard & 9.83 & 20.3 & 82.9 & 48.5 & std-52-2 & ICP Standard & 10.0 & 20.3 & 79.8 & 47.0 \\
\hline std-31-1 & ICP Standard & 10.0 & 20.6 & 83.3 & 47.7 & std-52-3 & ICP Standard & 10.0 & 20.4 & 80.3 & 46.9 \\
\hline std-31-2 & ICP Standard & 10.3 & 26.5 & 82.4 & 48.1 & std-53-1 & ICP Standard & 10.0 & 20.6 & 81.2 & 46.3 \\
\hline std-31-3 & ICP Standard & 10.2 & 21.5 & 81.7 & 46.5 & std-53-2 & ICP Standard & 10.2 & 20.1 & 82.3 & 47.4 \\
\hline std-32-1 & ICP Standard & 10.0 & 20.8 & 84.3 & 48.8 & std-53-3 & ICP Standard & 10.3 & 20.4 & 83.0 & 47.8 \\
\hline std-32-2 & ICP Standard & 10.0 & 24.6 & 83.4 & 47.6 & & & & & & \\
\hline
\end{tabular}


Table A-4. Measured Elemental Release of the PCT Leachates for C2 - Frit 510 Glass Samples

\begin{tabular}{|c|c|c|c|c|c|c|c|c|c|c|c|}
\hline \multirow[b]{2}{*}{$\begin{array}{c}\text { Solution } \\
\text { Identifier }\end{array}$} & \multirow[b]{2}{*}{$\begin{array}{c}\text { Original } \\
\text { Sample ID }\end{array}$} & \multicolumn{4}{|c|}{ Elemental Release from PSAL $(\mathrm{mg} / \mathrm{L})$} & \multirow[b]{2}{*}{$\begin{array}{c}\text { Solution } \\
\text { Identifier }\end{array}$} & \multirow[b]{2}{*}{$\begin{array}{c}\text { Original Sample } \\
\text { ID }\end{array}$} & \multicolumn{4}{|c|}{ Elemental Release from PSAL $(\mathrm{mg} / \mathrm{L})$} \\
\hline & & $\mathbf{L i}$ & B & $\mathbf{N a}$ & Si & & & $\mathbf{L i}$ & B & $\mathbf{N a}$ & $\mathbf{S i}$ \\
\hline D26 & C2-1000-1 & 9.71 & 10.5 & 34.8 & 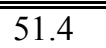 & F23 & C2-500-192 & 12.5 & 14.8 & 42.6 & 61.0 \\
\hline D42 & C2-1000-1 & 9.73 & 10.4 & 34.6 & 52.7 & F03 & $\mathrm{C} 2-500-192$ & 12.2 & 15.4 & 43.4 & 60.0 \\
\hline D64 & $\mathrm{C} 2-1000-1$ & 9.74 & 11.1 & 35.6 & 54.0 & F39 & $\mathrm{C} 2-500-192$ & 11.8 & 14.3 & 43.5 & 57.9 \\
\hline D50 & $\mathrm{C} 2-1000-12$ & 9.18 & 10.1 & 32.4 & 50.4 & F56 & C2-500-24 & 10.3 & 11.1 & 37.0 & 53.9 \\
\hline D31 & C2-1000-12 & 9.36 & 10.2 & 34.1 & 51.3 & F68 & C2-500-24 & 10.0 & 13.7 & 37.6 & 54.9 \\
\hline D68 & C2-1000-12 & 9.29 & 9.84 & 36.3 & 51.7 & F01 & C2-500-24 & 9.81 & 15.2 & 37.2 & 53.7 \\
\hline D60 & C2-1000-192 & 9.85 & 10.2 & 35.7 & 53.5 & F45 & C2-500-384 & 15.0 & 18.8 & 48.5 & 65.7 \\
\hline D36 & C2-1000-192 & 10.0 & 10.4 & 35.8 & 54.5 & F11 & C2-500-384 & 14.1 & 19.2 & 47.7 & 64.1 \\
\hline D17 & C2-1000-192 & 9.75 & 10.4 & 36.0 & 54.2 & F05 & C2-500-384 & 14.1 & 18.3 & 49.2 & 64.2 \\
\hline D37 & C2-1000-24 & 9.56 & 10.3 & 33.9 & 52.4 & F69 & C2-500-48 & 10.3 & 11.1 & 38.1 & 55.6 \\
\hline D18 & C2-1000-24 & 9.45 & 10.1 & 34.3 & 52.2 & F19 & C2-500-48 & 9.88 & 12.9 & 38.0 & 55.4 \\
\hline D67 & C2-1000-24 & 9.23 & 10.2 & 35.4 & 51.8 & F70 & C2-500-48 & 9.52 & 12.5 & 36.3 & 52.8 \\
\hline D66 & C2-1000-3 & 9.74 & 10.7 & 35.5 & 51.8 & F53 & C2-500-768 & 36.0 & 52.7 & 93.8 & 101 \\
\hline D52 & C2-1000-3 & 9.74 & 10.7 & 36.2 & 51.9 & F02 & $\mathrm{C} 2-500-768$ & 35.0 & 51.5 & 95.3 & 99.9 \\
\hline D38 & C2-1000-3 & 9.25 & 10.8 & 35.3 & 51.2 & F29 & C2-500-768 & 35.4 & 51.5 & 98.0 & 106 \\
\hline D55 & C2-1000-384 & 9.92 & 10.1 & 34.7 & 54.8 & F32 & C2-500-96 & 10.4 & 12.1 & 39.9 & 56.7 \\
\hline D28 & C2-1000-384 & 9.68 & 9.88 & 33.3 & 54.2 & F51 & C2-500-96 & 9.80 & 11.8 & 38.4 & 53.6 \\
\hline D06 & C2-1000-384 & 9.72 & 10.1 & 41.0 & 55.2 & F61 & C2-500-96 & 9.59 & 11.9 & 36.5 & 52.2 \\
\hline D30 & C2-1000-48 & 9.85 & 10.4 & 35.2 & 54.6 & E33 & C2-600-12 & 9.86 & 10.8 & 36.8 & 57.2 \\
\hline D02 & C2-1000-48 & 9.53 & 10.0 & 34.9 & 51.4 & E55 & C2-600-12 & 9.69 & 10.1 & 36.4 & 55.9 \\
\hline D16 & C2-1000-48 & 9.30 & 10.0 & 34.9 & 51.4 & E45 & C2-600-12 & 9.14 & 10.1 & 33.9 & 52.7 \\
\hline D56 & C2-1000-6 & 9.66 & 10.6 & 34.6 & 53.1 & F54 & C2-600-192 & 84.1 & 71.0 & 109 & 160 \\
\hline D39 & C2-1000-6 & 9.74 & 10.5 & 34.9 & 51.7 & F65 & C2-600-192 & 84.7 & 71.2 & 119 & 184 \\
\hline D54 & C2-1000-6 & 9.67 & 10.6 & 39.4 & 53.4 & F60 & C2-600-192 & 79.7 & 65.4 & 115 & 168 \\
\hline D08 & C2-1000-768 & 9.65 & 9.20 & 33.4 & 52.3 & E48 & C2-600-24 & 9.82 & 10.3 & 36.7 & 56.2 \\
\hline D15 & C2-1000-768 & 9.31 & 9.83 & 32.5 & 51.1 & E59 & C2-600-24 & 10.0 & 10.5 & 37.5 & 57.9 \\
\hline D47 & C2-1000-768 & 9.04 & 9.27 & 32.8 & 50.6 & E42 & C2-600-24 & 9.84 & 10.8 & 36.5 & 56.8 \\
\hline D22 & C2-1000-96 & 10.1 & 10.9 & 35.1 & 55.0 & F17 & C2-600-384 & 111 & 153 & 232 & 220 \\
\hline D13 & C2-1000-96 & 9.82 & 10.3 & 36.4 & 52.1 & F09 & C2-600-384 & 103 & 142 & 212 & 205 \\
\hline D74 & C2-1000-96 & 10.0 & 11.0 & 37.1 & 55.4 & F40 & C2-600-384 & 103 & 145 & 211 & 204 \\
\hline
\end{tabular}


Table A-5. Measured Elemental Release of the PCT Leachates for C2 - Frit 510 Glass Samples

\begin{tabular}{|c|c|c|c|c|c|c|c|c|c|c|c|}
\hline \multirow[b]{2}{*}{$\begin{array}{l}\text { Solution } \\
\text { Identifier }\end{array}$} & \multirow[b]{2}{*}{$\begin{array}{c}\text { Original } \\
\text { Sample ID }\end{array}$} & \multicolumn{4}{|c|}{ Elemental Release from PSAL $(\mathrm{mg} / \mathrm{L})$} & \multirow[b]{2}{*}{$\begin{array}{c}\text { Solution } \\
\text { Identifier }\end{array}$} & \multirow[b]{2}{*}{$\begin{array}{c}\text { Original Sample } \\
\text { ID } \\
\end{array}$} & \multicolumn{4}{|c|}{ Elemental Release from PSAL $(\mathrm{mg} / \mathrm{L})$} \\
\hline & & $\mathbf{L i}$ & B & $\mathbf{N a}$ & Si & & & $\mathbf{L i}$ & B & $\mathbf{N a}$ & $\mathbf{S i}$ \\
\hline E06 & C2-600-48 & 15.4 & 12.9 & 44.4 & 69.2 & E71 & $\mathrm{C} 2-700-96$ & 12.2 & 13.9 & 44.1 & 60.6 \\
\hline E03 & $\mathrm{C} 2-600-48$ & 15.6 & 12.8 & 45.3 & 70.0 & E64 & C2-700-96 & 11.4 & 12.8 & 41.3 & 57.5 \\
\hline E57 & $\mathrm{C} 2-600-48$ & 15.9 & 13.2 & 45.4 & 70.2 & E21 & $\mathrm{C} 2-700-96$ & 11.5 & 13.2 & 41.6 & 58.1 \\
\hline F16 & $\mathrm{C} 2-600-768$ & 146 & 300 & 418 & 231 & E56 & C2-800-12 & 9.76 & 10.3 & 36.3 & 58.2 \\
\hline F42 & C2-600-768 & 143 & 293 & 393 & 231 & E38 & C2-800-12 & 9.24 & 9.49 & 34.6 & 55.4 \\
\hline F64 & C2-600-768 & 144 & 296 & 408 & 233 & E36 & C2-800-12 & 9.24 & 9.62 & 34.7 & 55.3 \\
\hline F73 & C2-600-96 & 31.5 & 21.0 & 56.7 & 92.8 & E58 & C2-800-192 & 9.32 & 9.86 & 35.7 & 56.3 \\
\hline F33 & C2-600-96 & 31.5 & 20.1 & 56.7 & 100 & E41 & C2-800-192 & 9.35 & 9.51 & 35.4 & 56.2 \\
\hline F34 & C2-600-96 & 30.3 & 21.4 & 57.7 & 98.6 & E31 & C2-800-192 & 9.14 & 9.94 & 33.8 & 55.1 \\
\hline E49 & C2-700-12 & 9.52 & 10.0 & 36.4 & 57.1 & E27 & C2-800-24 & 9.17 & 9.54 & 34.3 & 54.6 \\
\hline E19 & C2-700-12 & 9.46 & 9.72 & 36.0 & 56.3 & E34 & C2-800-24 & 9.42 & 9.63 & 35.4 & 56.6 \\
\hline E26 & C2-700-12 & 9.62 & 9.95 & 35.2 & 57.3 & E51 & C2-800-24 & 9.43 & 9.93 & 35.1 & 56.7 \\
\hline E53 & C2-700-192 & 46.7 & 41.0 & 96.1 & 110 & E61 & C2-800-3 & 9.06 & 9.60 & 33.5 & 53.6 \\
\hline E16 & C2-700-192 & 44.1 & 39.1 & 91.7 & 104.8 & E17 & C2-800-3 & 8.94 & 9.01 & 33.2 & 53.3 \\
\hline E05 & C2-700-192 & 44.0 & 39.6 & 91.4 & 105 & E74 & C2-800-3 & 9.18 & 9.79 & 34.0 & 54.6 \\
\hline E04 & C2-700-24 & 9.89 & 10.2 & 36.8 & 59.8 & E67 & C2-800-384 & 9.14 & 9.63 & 35.3 & 55.4 \\
\hline E24 & C2-700-24 & 10.1 & 10.1 & 37.9 & 60.4 & E10 & C2-800-384 & 9.20 & 9.28 & 34.7 & 55.8 \\
\hline E47 & C2-700-24 & 9.93 & 10.1 & 36.8 & 58.6 & E50 & C2-800-384 & 9.21 & 9.59 & 34.7 & 55.2 \\
\hline E66 & C2-700-384 & 62.2 & 47.6 & 109 & 134 & E73 & C2-800-48 & 8.95 & 9.40 & 33.5 & 54.0 \\
\hline E35 & C2-700-384 & 58.7 & 43.1 & 102 & 129 & E44 & C2-800-48 & 9.18 & 9.57 & 34.6 & 55.2 \\
\hline E01 & C2-700-384 & 58.0 & 43.3 & 99.6 & 127 & E20 & C2-800-48 & 9.44 & 10.3 & 35.5 & 56.0 \\
\hline E62 & C2-700-48 & 9.78 & 10.0 & 36.0 & 58.6 & E40 & C2-800-6 & 9.02 & 9.33 & 34.4 & 54.5 \\
\hline E32 & C2-700-48 & 9.64 & 9.59 & 35.9 & 57.3 & E11 & C2-800-6 & 9.00 & 9.09 & 33.9 & 53.6 \\
\hline E12 & C2-700-48 & 9.57 & 9.78 & 34.9 & 57.3 & E29 & C2-800-6 & 9.18 & 9.71 & 34.1 & 54.3 \\
\hline E63 & C2-700-6 & 9.07 & 9.42 & 34.9 & 54.2 & E13 & C2-800-768 & 9.26 & 9.59 & 34.9 & 57.3 \\
\hline E14 & C2-700-6 & 9.31 & 9.42 & 36.7 & 56.8 & E08 & C2-800-768 & 9.40 & 9.69 & 35.0 & 56.6 \\
\hline E60 & C2-700-6 & 9.32 & 9.76 & 36.0 & 56.1 & E43 & C2-800-768 & 9.73 & 10.2 & 35.7 & 58.3 \\
\hline E15 & C2-700-768 & 59.9 & 45.2 & 102 & 127 & E69 & C2-800-96 & 9.74 & 10.4 & 36.3 & 57.7 \\
\hline E25 & C2-700-768 & 61.4 & 47.6 & 108 & 132 & E46 & C2-800-96 & 9.56 & 9.67 & 35.3 & 57.1 \\
\hline E39 & C2-700-768 & 61.8 & 47.4 & 106 & 132 & E68 & C2-800-96 & 9.65 & 10.1 & 35.8 & 56.9 \\
\hline
\end{tabular}


Table A-6. Measured Elemental Release of the PCT Leachates for C2 - Frit 510 and C4 - 418 Glass Samples

\begin{tabular}{|c|c|c|c|c|c|c|c|c|c|c|c|}
\hline \multirow[b]{2}{*}{$\begin{array}{l}\text { Solution } \\
\text { Identifier }\end{array}$} & \multirow[b]{2}{*}{$\begin{array}{c}\text { Original } \\
\text { Sample ID }\end{array}$} & \multicolumn{4}{|c|}{ Elemental Release from PSAL $(\mathrm{mg} / \mathrm{L})$} & \multirow[b]{2}{*}{$\begin{array}{c}\text { Solution } \\
\text { Identifier }\end{array}$} & \multirow[b]{2}{*}{$\begin{array}{c}\text { Original Sample } \\
\text { ID }\end{array}$} & \multicolumn{4}{|c|}{ Elemental Release from PSAL $(\mathrm{mg} / \mathrm{L})$} \\
\hline & & $\mathbf{L i}$ & B & $\mathbf{N a}$ & Si & & & $\mathbf{L i}$ & B & $\mathbf{N a}$ & $\mathbf{S i}$ \\
\hline D59 & $\mathrm{C} 2-900-1$ & 9.25 & 10.0 & 32.3 & 51.0 & D04 & $\mathrm{C} 2-\mathrm{CCC}$ & 10.0 & 10.0 & 33.9 & 56.7 \\
\hline D71 & C2-900-1 & 9.86 & 10.0 & 35.5 & 54.3 & D57 & $\mathrm{C} 2-\mathrm{CCC}$ & 9.72 & 9.74 & 33.9 & 54.4 \\
\hline D41 & C2-900-1 & 9.29 & 9.66 & 35.6 & 52.2 & D63 & $\mathrm{C} 2-\mathrm{CCC}$ & 9.73 & 9.77 & 37.0 & 54.1 \\
\hline D25 & C2-900-12 & 10.0 & 10.0 & 35.4 & 54.4 & E72 & $\mathrm{C} 2-\mathrm{CCC}$ & 9.82 & 10.2 & 35.9 & 58.3 \\
\hline D12 & C2-900-12 & 10.0 & 10.8 & 36.1 & 55.2 & E07 & $\mathrm{C} 2-\mathrm{CCC}$ & 9.69 & 10.1 & 34.9 & 57.9 \\
\hline D69 & C2-900-12 & 9.44 & 10.2 & 34.2 & 54.2 & E22 & $\mathrm{C} 2-\mathrm{CCC}$ & 8.99 & 9.38 & 31.8 & 53.4 \\
\hline D43 & C2-900-192 & 9.91 & 10.3 & 34.8 & 55.5 & D72 & C2-Q & 10.2 & 10.7 & 35.9 & 55.7 \\
\hline D07 & C2-900-192 & 9.69 & 10.0 & 33.4 & 54.3 & D62 & C2-Q & 10.1 & 10.7 & 35.9 & 55.4 \\
\hline D09 & C2-900-192 & 9.62 & 10.3 & 37.4 & 53.7 & D33 & C2-Q & 10.0 & 10.4 & 37.7 & 53.9 \\
\hline D51 & C2-900-24 & 9.82 & 9.92 & 35.3 & 54.3 & E23 & C2-Q & 9.62 & 10.3 & 34.9 & 55.8 \\
\hline D35 & C2-900-24 & 11.2 & 11.1 & 39.5 & 62.5 & E02 & C2-Q & 9.54 & 9.78 & 34.9 & 54.8 \\
\hline D20 & C2-900-24 & 9.04 & 9.80 & 33.6 & 51.8 & E37 & C2-Q & 9.85 & 11.0 & 35.6 & 57.4 \\
\hline D65 & C2-900-3 & 9.32 & 9.56 & 32.4 & 51.4 & F47 & C2-Q & 10.2 & 10.8 & 35.9 & 55.2 \\
\hline D03 & C2-900-3 & 9.20 & 9.85 & 33.7 & 51.0 & F49 & C2-Q & 9.92 & 15.2 & 36.3 & 54.9 \\
\hline D58 & C2-900-3 & 9.04 & 9.59 & 34.2 & 51.0 & F21 & C2-Q & 9.76 & 11.2 & 37.3 & 55.5 \\
\hline D70 & C2-900-384 & 10.3 & 10.5 & 36.1 & 57.2 & G62 & $\mathrm{C} 4-\mathrm{CCC}$ & 12.4 & 7.86 & 54.1 & 74.5 \\
\hline D46 & C2-900-384 & 10.0 & 10.2 & 35.8 & 55.6 & G45 & $\mathrm{C} 4-\mathrm{CCC}$ & 12.0 & 6.85 & 53.9 & 70.9 \\
\hline D19 & C2-900-384 & 10.1 & 10.3 & 38.6 & 56.3 & G22 & $\mathrm{C} 4-\mathrm{CCC}$ & 12.3 & 7.07 & 54.7 & 76.1 \\
\hline D34 & C2-900-48 & 9.87 & 10.1 & 35.1 & 54.5 & H71 & $\mathrm{C} 4-\mathrm{CCC}$ & 12.2 & 7.30 & 53.3 & 71.3 \\
\hline D48 & C2-900-48 & 9.70 & 10.0 & 33.4 & 54.8 & H01 & C4-CCC & 12.3 & 7.23 & 53.7 & 73.5 \\
\hline D11 & C2-900-48 & 9.73 & 10.1 & 38.1 & 54.2 & H61 & $\mathrm{C} 4-\mathrm{CCC}$ & 12.2 & 7.29 & 54.2 & 71.7 \\
\hline D21 & C2-900-6 & 9.61 & 10.0 & 34.5 & 53.2 & F52 & C4-Q & 13.5 & 8.90 & 61.7 & 81.4 \\
\hline D40 & C2-900-6 & 9.47 & 10.0 & 34.2 & 54.2 & F22 & C4-Q & 12.9 & 9.23 & 63.2 & 76.0 \\
\hline D32 & C2-900-6 & 9.63 & 10.3 & 36.2 & 53.5 & F71 & C4-Q & 12.8 & 11.5 & 62.4 & 75.3 \\
\hline D49 & C2-900-768 & 9.74 & 10.0 & 34.6 & 55.5 & G17 & C4-Q & 12.6 & 8.46 & 56.8 & 74.6 \\
\hline D14 & C2-900-768 & 9.82 & 9.89 & 34.6 & 55.8 & G05 & C4-Q & 12.5 & 8.13 & 55.0 & 66.4 \\
\hline D23 & C2-900-768 & 9.69 & 10.5 & 36.7 & 55.4 & G74 & C4-Q & 12.1 & 7.96 & 60.5 & 76.2 \\
\hline D61 & C2-900-96 & 10.2 & 10.3 & 36.4 & 55.3 & $\mathrm{H} 30$ & C4-Q & 12.6 & 8.10 & 59.0 & 73.8 \\
\hline D53 & C2-900-96 & 10.2 & 10.4 & 37.6 & 55.5 & $\mathrm{H} 17$ & C4-Q & 12.6 & 8.14 & 57.9 & 76.0 \\
\hline D10 & C2-900-96 & 9.75 & 10.4 & 36.7 & 55.0 & H06 & C4-Q & 12.6 & 8.05 & 58.4 & 74.0 \\
\hline
\end{tabular}


Table A-7. Measured Elemental Release of the PCT Leachates for the C4 - 418 Glass Samples

\begin{tabular}{|c|c|c|c|c|c|c|c|c|c|c|c|}
\hline \multirow[b]{2}{*}{$\begin{array}{c}\text { Solution } \\
\text { Identifier }\end{array}$} & \multirow[b]{2}{*}{$\begin{array}{c}\text { Original Sample } \\
\text { ID } \\
\end{array}$} & \multicolumn{4}{|c|}{ Elemental Release from PSAL (mg/L) } & \multirow[b]{2}{*}{$\begin{array}{c}\text { Solution } \\
\text { Identifier } \\
\end{array}$} & \multirow[b]{2}{*}{$\begin{array}{c}\text { Original Sample } \\
\text { ID } \\
\end{array}$} & \multicolumn{4}{|c|}{ Elemental Release from PSAL $(\mathrm{mg} / \mathrm{L})$} \\
\hline & & $\mathbf{L i}$ & B & $\mathbf{N a}$ & Si & & & $\mathbf{L i}$ & B & $\mathbf{N a}$ & Si \\
\hline G53 & C4-1000-1 & 13.63 & 8.7 & 64.0 & 81.9 & H65 & C4-500-192 & 13.4 & 8.7 & 64.1 & 78.7 \\
\hline G12 & C4-1000-1 & 13.00 & 8.0 & 62.7 & 79.4 & $\mathrm{H} 08$ & C4-500-192 & 14.0 & 9.2 & 68.0 & 85.1 \\
\hline G30 & C4-1000-1 & 13.07 & 8.0 & 62.0 & 80.5 & H53 & C4-500-192 & 13.5 & 8.9 & 65.0 & 79.9 \\
\hline G46 & C4-1000-12 & 13.28 & 8.4 & 62.4 & 79.2 & $\mathrm{H} 40$ & C4-500-24 & 14.6 & 9.9 & 69.5 & 85.6 \\
\hline G47 & C4-1000-12 & 13.05 & 8.3 & 61.7 & 79.7 & $\mathrm{H} 50$ & C4-500-24 & 13.9 & 9.3 & 66.0 & 83.4 \\
\hline G08 & C4-1000-12 & 12.98 & 8.28 & 67.1 & 83.3 & $\mathrm{H} 46$ & C4-500-24 & 14.28 & 9.4 & 69.6 & 84.0 \\
\hline G36 & C4-1000-192 & 13.24 & 8.3 & 63.2 & 80.1 & H52 & C4-500-384 & 15.9 & 10.5 & 71.8 & 88.2 \\
\hline G31 & C4-1000-192 & 13.0 & 8.0 & 63.1 & 80.0 & H15 & C4-500-384 & 15.3 & 10.2 & 69.6 & 86.4 \\
\hline G65 & C4-1000-192 & 12.92 & 8.6 & 62.4 & 79.7 & H37 & C4-500-384 & 15.3 & 10.2 & 70.9 & 88.0 \\
\hline G51 & C4-1000-24 & 12.83 & 8.2 & 60.6 & 76.8 & $\mathrm{H} 68$ & C4-500-48 & 12.8 & 8.3 & 61.5 & 77.0 \\
\hline G02 & C4-1000-24 & 12.76 & 7.9 & 62.0 & 76.7 & $\mathrm{H} 73$ & C4-500-48 & 13.03 & 8.3 & 62.6 & 77.0 \\
\hline G34 & C4-1000-24 & 12.61 & 7.7 & 60.7 & 77.5 & H11 & C4-500-48 & 13.51 & 9.0 & 65.6 & 80.1 \\
\hline G33 & C4-1000-3 & 13.04 & 8.1 & 61.4 & 77.9 & H69 & C4-500-768 & 15.9 & 10.3 & 67.7 & 86 \\
\hline G55 & C4-1000-3 & 12.85 & 8.2 & 60.5 & 78.9 & $\mathrm{H} 25$ & C4-500-768 & 15.4 & 10.0 & 66.4 & 85.5 \\
\hline G49 & C4-1000-3 & 12.79 & 7.8 & 60.7 & 78.8 & H35 & C4-500-768 & 15.7 & 10.2 & 67.7 & 85 \\
\hline G44 & C4-1000-384 & 13.00 & 9.0 & 60.8 & 79.2 & $\mathrm{H} 72$ & C4-500-96 & 13.1 & 8.5 & 61.9 & 76.8 \\
\hline G56 & C4-1000-384 & 12.72 & 7.98 & 61.7 & 76.7 & H39 & C4-500-96 & 13.15 & 8.4 & 62.6 & 77.6 \\
\hline G27 & C4-1000-384 & 12.31 & 7.6 & 64.8 & 80.1 & $\mathrm{H} 27$ & C4-500-96 & 13.29 & 8.5 & 63.5 & 78.5 \\
\hline G66 & C4-1000-48 & 12.83 & 8.4 & 59.2 & 77.1 & F15 & C4-600-12 & 12.35 & 9.0 & 56.5 & 69.0 \\
\hline G39 & C4-1000-48 & 12.83 & 8.2 & 60.5 & 77.8 & F04 & C4-600-12 & 11.73 & 11.2 & 55.2 & 70.0 \\
\hline G04 & C4-1000-48 & 12.25 & 7.7 & 63.0 & 77.6 & F66 & C4-600-12 & 11.65 & 8.7 & 57.1 & 72.5 \\
\hline G54 & C4-1000-6 & 12.66 & 8.5 & 58.8 & 76.0 & F44 & C4-600-192 & 128.5 & 402.8 & 999 & 478 \\
\hline G50 & C4-1000-6 & 12.26 & 7.5 & 57.9 & 74.3 & F08 & C4-600-192 & 128.5 & 403.8 & 1010 & 481 \\
\hline G29 & C4-1000-6 & 12.56 & 7.5 & 59.4 & 77.0 & F55 & C4-600-192 & 128.8 & 407.2 & 1010 & 494 \\
\hline G43 & C4-1000-768 & 12.23 & 7.46 & 56.7 & 74.4 & F06 & C4-600-24 & 13.04 & 8.4 & 60.1 & 77.4 \\
\hline G38 & C4-1000-768 & 12.02 & 6.94 & 57.4 & 73.0 & F12 & C4-600-24 & 13.0 & 10.3 & 62.6 & 80.9 \\
\hline G21 & C4-1000-768 & 12.58 & 6.51 & 55.8 & 66.1 & F36 & C4-600-24 & 12.26 & 8.9 & 60.0 & 71.7 \\
\hline G10 & C4-1000-96 & 13.0 & 8.2 & 60.9 & 78.5 & F41 & C4-600-384 & 140 & 503 & 1210 & 555 \\
\hline G48 & C4-1000-96 & 12.48 & 7.7 & 59.3 & 76.7 & F28 & C4-600-384 & 139 & 499 & 1210 & 556 \\
\hline G32 & C4-1000-96 & 12.7 & 7.8 & 60.0 & 79.4 & F25 & C4-600-384 & 34 & 56 & 94 & 97 \\
\hline
\end{tabular}


Table A-8. Measured Elemental Release of the PCT Leachates for the C4 - 418 Glass Samples

\begin{tabular}{|c|c|c|c|c|c|c|c|c|c|c|c|}
\hline \multirow[b]{2}{*}{$\begin{array}{c}\text { Solution } \\
\text { Identifier }\end{array}$} & \multirow[b]{2}{*}{$\begin{array}{c}\text { Original Sample } \\
\text { ID } \\
\end{array}$} & \multicolumn{4}{|c|}{ Elemental Release from PSAL $(\mathrm{mg} / \mathrm{L})$} & \multirow[b]{2}{*}{$\begin{array}{c}\text { Solution } \\
\text { Identifier }\end{array}$} & \multirow[b]{2}{*}{$\begin{array}{c}\text { Original Sample } \\
\text { ID } \\
\end{array}$} & \multicolumn{4}{|c|}{ Elemental Release from PSAL $(\mathrm{mg} / \mathrm{L})$} \\
\hline & & $\mathbf{L i}$ & B & $\mathbf{N a}$ & $\mathbf{S i}$ & & & $\mathbf{L i}$ & B & $\mathbf{N a}$ & $\mathbf{S i}$ \\
\hline F31 & $\mathrm{C} 4-600-48$ & 20.0 & 17.6 & 81.8 & 87.4 & $\mathrm{H} 45$ & C4-700-96 & 17.6 & 9.3 & 76.4 & 94.1 \\
\hline F14 & C4-600-48 & 19.0 & 18.3 & 77.5 & 87.8 & $\mathrm{H} 22$ & C4-700-96 & 16.5 & 8.8 & 72.6 & 89.7 \\
\hline F43 & C4-600-48 & 17.9 & 15.8 & 76.4 & 85.2 & $\mathrm{H} 44$ & C4-700-96 & 17.3 & 9.1 & 76.9 & 92.8 \\
\hline F20 & C4-600-768 & 148 & 539 & 1270 & 589 & $\mathrm{H} 41$ & C4-800-12 & 13.93 & 8.4 & 67.3 & 82.8 \\
\hline F18 & C4-600-768 & 144 & 517 & 1260 & 568 & H62 & C4-800-12 & 13.66 & 8.31 & 66.9 & 82.4 \\
\hline F62 & C4-600-768 & 146 & 539 & 1260 & 595 & $\mathrm{H} 43$ & C4-800-12 & 13.69 & 8.33 & 67.6 & 82.4 \\
\hline F35 & C4-600-96 & 103.0 & 196.1 & 552.5 & 330.3 & H59 & C4-800-192 & 12.60 & 7.85 & 62.8 & 78.8 \\
\hline F59 & C4-600-96 & 102.8 & 191.7 & 557.2 & 315 & H31 & C4-800-192 & 13.26 & 8.18 & 66.9 & 83.7 \\
\hline F46 & C4-600-96 & 103.6 & 194.5 & 534.8 & 324.9 & $\mathrm{H} 02$ & C4-800-192 & 13.23 & 8.10 & 65.6 & 81.2 \\
\hline F24 & C4-700-12 & 13.25 & 8.7 & 62.4 & 78.6 & H66 & C4-800-24 & 12.99 & 7.89 & 62.3 & 77.4 \\
\hline F57 & C4-700-12 & 12.72 & 8.11 & 63.6 & 77.0 & H33 & C4-800-24 & 13.30 & 8.11 & 65.6 & 79.9 \\
\hline F27 & C4-700-12 & 12.77 & 10.08 & 62.9 & 75.5 & H64 & C4-800-24 & 13.81 & 8.43 & 68.1 & 83.1 \\
\hline $\mathrm{H} 26$ & C4-700-192 & 54.7 & 13.0 & 113.1 & 160 & H32 & C4-800-3 & 13.47 & 8.16 & 64.6 & 80.0 \\
\hline H09 & C4-700-192 & 51.3 & 12.5 & 113.2 & 158.6 & H19 & C4-800-3 & 12.94 & 7.82 & 61.8 & 78.4 \\
\hline H16 & C4-700-192 & 53.9 & 13.4 & 118.9 & 166 & H34 & C4-800-3 & 13.40 & 8.23 & 65.2 & 80.4 \\
\hline $\mathrm{F} 37$ & C4-700-24 & 13.40 & 8.0 & 63.0 & 76.9 & $\mathrm{H} 07$ & C4-800-384 & 13.48 & 8.22 & 67.7 & 83.2 \\
\hline F72 & C4-700-24 & 12.7 & 7.6 & 62.7 & 77.5 & $\mathrm{H} 29$ & C4-800-384 & 12.16 & 7.37 & 60.7 & 74.4 \\
\hline F26 & C4-700-24 & 12.69 & 10.3 & 64.6 & 80.4 & $\mathrm{H} 47$ & C4-800-384 & 12.57 & 7.77 & 63.5 & 77.7 \\
\hline H14 & C4-700-384 & 54.5 & 13.7 & 119 & 164 & $\mathrm{H} 70$ & C4-800-48 & 13.62 & 8.19 & 66.2 & 81.1 \\
\hline H12 & C4-700-384 & 53.1 & 13.1 & 115 & 160 & $\mathrm{H} 42$ & C4-800-48 & 13.53 & 8.20 & 66.1 & 81.6 \\
\hline $\mathrm{H} 48$ & C4-700-384 & 53.4 & 13.2 & 114.1 & 168 & $\mathrm{H} 23$ & C4-800-48 & 12.28 & 7.6 & 61.6 & 76.0 \\
\hline H63 & C4-700-48 & 13.68 & 7.8 & 66.4 & 79.5 & H51 & C4-800-6 & 13.35 & 8.21 & 64.0 & 79.4 \\
\hline H56 & C4-700-48 & 13.31 & 7.64 & 64.4 & 80.7 & $\mathrm{H} 49$ & C4-800-6 & 12.73 & 7.77 & 62.5 & 78.8 \\
\hline H60 & C4-700-48 & 13.02 & 7.50 & 62.4 & 75.8 & $\mathrm{H} 21$ & C4-800-6 & 12.90 & 7.74 & 62.9 & 77.2 \\
\hline F50 & C4-700-6 & 12.93 & 8.59 & 59.8 & 77.0 & $\mathrm{H} 58$ & C4-800-768 & 12.45 & 7.49 & 60.5 & 76.1 \\
\hline F38 & C4-700-6 & 12.26 & 8.17 & 59.5 & 72.5 & $\mathrm{H} 20$ & C4-800-768 & 12.15 & 7.49 & 59.1 & 76.3 \\
\hline F67 & C4-700-6 & 12.17 & 7.88 & 62.5 & 75.7 & $\mathrm{H} 04$ & C4-800-768 & 12.40 & 7.5 & 61.2 & 76.0 \\
\hline H55 & C4-700-768 & 53.7 & 18.2 & 150 & 173 & H36 & C4-800-96 & 12.42 & 7.5 & 59.8 & 74.1 \\
\hline H38 & C4-700-768 & 52.0 & 17.6 & 142 & 168 & $\mathrm{H} 10$ & C4-800-96 & 12.49 & 7.56 & 59.9 & 77.4 \\
\hline $\mathrm{H} 24$ & C4-700-768 & 55.0 & 18.6 & 140 & 171 & $\mathrm{H} 54$ & C4-800-96 & 12.61 & 7.9 & 62.3 & 76.6 \\
\hline
\end{tabular}


Table A-9. Measured Elemental Release of the PCT Leachates for the C4 - 418 Glass Samples

\begin{tabular}{||c|c|c|c|c|c||}
\hline \multicolumn{2}{|c|}{} & \multicolumn{4}{|c|}{ Elemental Release from PSAL (mg/L) } \\
\hline $\begin{array}{c}\text { Solution } \\
\text { Identifier }\end{array}$ & $\begin{array}{c}\text { Original Sample } \\
\text { ID }\end{array}$ & Li & B & Na & Si \\
\hline G14 & C4-900-1 & 12.87 & 8.0 & 58.3 & 76.5 \\
\hline G61 & C4-900-1 & 12.45 & 7.4 & 56.7 & 75.4 \\
\hline G42 & C4-900-1 & 13.07 & 7.85 & 59.4 & 81.2 \\
\hline G09 & C4-900-12 & 12.9 & 7.8 & 61.0 & 77.8 \\
\hline G35 & C4-900-12 & 12.4 & 7.7 & 59.3 & 74.7 \\
\hline G72 & C4-900-12 & 12.46 & 7.2 & 58.7 & 77.0 \\
\hline G60 & C4-900-192 & 12.52 & 7.8 & 60.1 & 76.4 \\
\hline G73 & C4-900-192 & 12.29 & 7.5 & 59.2 & 77.6 \\
\hline G20 & C4-900-192 & 11.86 & 7.3 & 63.0 & 78.7 \\
\hline G63 & C4-900-24 & 12.68 & 8.03 & 60.1 & 76.3 \\
\hline G58 & C4-900-24 & 11.9 & 7.0 & 57.5 & 72.8 \\
\hline G19 & C4-900-24 & 11.96 & 7.16 & 63.3 & 76.7 \\
\hline G11 & C4-900-3 & 13.46 & 8.46 & 62.1 & 80.8 \\
\hline G37 & C4-900-3 & 12.82 & 7.81 & 61.1 & 77.1 \\
\hline G23 & C4-900-3 & 12.81 & 8.03 & 64.6 & 81.8 \\
\hline G18 & C4-900-384 & 11.7 & 7.3 & 56.8 & 72.2 \\
\hline G26 & C4-900-384 & 11.5 & 7.0 & 57.0 & 71.2 \\
\hline G69 & C4-900-384 & 11.9 & 7.0 & 58.5 & 75.4 \\
\hline G70 & C4-900-48 & 12.33 & 7.7 & 58.7 & 75.8 \\
\hline G06 & C4-900-48 & 11.90 & 7.1 & 58.1 & 73.3 \\
\hline G01 & C4-900-48 & 12.00 & 7.5 & 64.2 & 79.7 \\
\hline G25 & C4-900-6 & 12.42 & 7.8 & 59.3 & 73.8 \\
\hline G52 & C4-900-6 & 12.30 & 7.3 & 59.7 & 74.3 \\
\hline G59 & C4-900-6 & 12.09 & 7.1 & 58.5 & 74.9 \\
\hline G64 & C4-900-768 & 11.93 & 7.3 & 57.4 & 72.2 \\
\hline G16 & C4-900-768 & 11.83 & 7.18 & 57.6 & 73.7 \\
\hline G71 & C4-900-768 & 11.29 & 7.2 & 55.8 & 70.7 \\
\hline G13 & C4-900-96 & 12.5 & 7.8 & 60.4 & 75.5 \\
\hline G68 & C4-900-96 & 12.0 & 7.8 & 58.6 & 72.0 \\
\hline \hline
\end{tabular}




\section{Distribution:}
A. B. Barnes, 999-W
A.R. Shafer, 704-27S
B. A. Hamm, 766-H
B. J. Giddings, 786-5A
C. C. Herman, 999-W
C. J. Bannochie, 773-42A
C. L. Crawford, 773-42A
C. M. Jantzen, 773-A
D. A. Crowley, 773-43A
D. C. Sherburne, 704-S
D. D. Larsen, 766-H
D. H. Miller, 999-W
D. J. McCabe, 773-42A
D. K. Peeler, 999-W
E. W. Holtzscheiter, 704-
F. C. Johnson, 999-W
F. M. Pennebaker, 773-42A
H. B. Shah, 766-H
J. E. Occhipinti, 704-S
J. F. Iaukea, 704-30S
J. M. Bricker, 704-27S
J. M. Gillam, 766-H
J. P. Vaughan, 773-41 A
J. W. Ray, 704-S
K. M. Fox, 999-W
M. A. Broome, 704-29S
M. E. Smith, 704-30S
M. E. Stone, 999-W
P.L. Lee, 773-42A
R. N. Hinds, 704-S
R. T. McNew, 704-27S
S. D. Fink, 773-A
S. L. Marra, 773-A
T. B. Edwards, 999-W
T. L. Fellinger, 704-26S
W. R. Wilmarth, 773-A 